九州大学学術情報リポジトリ

Kyushu University Institutional Repository

\title{
Opisthobranchia Of The Ryukyu (Okinawa) Islands
}

Baba, Kikutaro

The Amakusa Marine Biological Laboratory, Tomioka, Kumamoto-ken.

https://doi.org/10.5109/22580

出版情報: 九州大学大学院農学研究院紀要. 5 (1)，pp.1-50，1936-03. Kyushu Imperial University バージョン：

権利関係 : 
Journal of the Department of Agriculture, Kyt̂shû Imperial Iniversity, Vol. 5, No. I.

March 20, 1936

\title{
OPISTHOBRANCHIA OF THE RYÛKYÛ (OKINAWA) ISLANDS ${ }^{1}$
}

\author{
Kikutarô BABA
}

\section{INTRODUCTION}

The present paper is intended to give an account of the Opisthobranch fauna of the Ryûkyû (Okinawa) Islands by bringing together all the records to date and by studying (1) fresh material collected during a survey of the coral reefs of this district by Professor Hiroshi OHshima, Professor Teisô Esaki, Mr. Hayato IKEDa and the author, during the months of June and July 1934, (2) the living and dead specimens collected by Messrs Chôsen SENAHA, Tsutomu Masaki, Chûchoku Hazama, Yoshimaro IrISA, and (3) material preserved in the Third Middle School (Nago) and the Fourth Middle School (Miyako), Okinawa-ken. It is a pleasure to the author to tender his hearty thanks to these gentlemen for kindly placing their valuable collection at his disposal for study. A part of the expense of this survey was met by a grant from the Foundation for the Promotion of Scientific and Industrial Research of Japan.

The first of the species is recorded by Adams and RfEvf. in "Zoology of the voyage of H.M.S. Samarang," 1850:

1. Tethys dactylomela $\{\mathrm{R}+\mathrm{x}$ ri\}, as Aplysia fimbriata from Miyako-shima.

The following species are recorded by STIMPSON in "Descriptions of some of the new marine Invertebrata from the Chinese and Japanese seas." Proc. Acad. Nat. Sci. Philadelphia, 1855. No. 73.

1) Contributions from the Zoological Laboratory, Kyûshû Imperial University. 
1. Tethys laevigata (STm1siv), as Aplysia lacvigata, from Amami-Oshima.

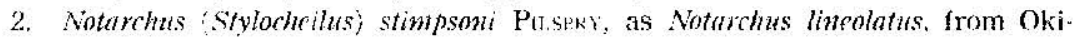
naw:

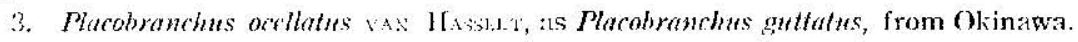

4. Ciymnotoris muculatu Synms.., from Okinawa.

5. Dendrodoris (Dendrodoris) nigm (Sissiste), as Doris nigra, from Okinawat :and Kikai-git-shima.

Of these, nos. 2,3 and 5 are well established, but nos. 1 and 4 appear to be invalid.

The following species are recorded by Eu.roT in "Japanese Nudibranchs." Journ. Coll. Sci. Imp. Univ. Tókyô, vol. 35, art. 1, 1913.

7. Halgerda graphira B.sinow and Hewr.w, from Okinawa.

2. Argus crucntus (Qtur and Gamard), as Platydoris conenta, from Ishigaki shima.

3. Phyllidia (Phyllidiello) pustulosa Civ1:r, from Okinawa-shima.

The following species is recorded by HiRast: in "Figuraro de Japanaj Bestoj, Moluskoj," 1927.

1. Dolubella siapula (MARTN), as Dolabella sp., from Okinawa.

The present study has led the author to place in the list of the fauna of the region in question 8 species which seem to be new to science and 9 which have not been recorded from the Japanese waters. A comprehensive list of the species known to occur in the Ryûkyû Islands may thus be given as follows:

\section{Opisthobranchia}

Order 1. Pleurocoela (= Tectibranchia)

Tribe 1. Cephalaspidea

Family Atyidx

Subfamily Cryptophthalminxe

1. Cryptophthalmus smaragdinus (RüPppex. and LeuCKART, 1828)

Family Aglaiidæ

2. Aglaia cyanea (MARTENS, 1879)

Tribe 2. Anaspidea

Family Tethyidxe

Subfamily Tethyinæe

3. Tethys dactylomela (RANG, 1828)

*4. Tethys laevigata (STIMPSON, 1855)

5. Tethys hirasei nov. sp. 


\section{Subfamily Dolabriferinæe}

6. Dolabrifera tahitensis PEASE, 1861

7. Notarchus (Stylocheilus) stimpsoni PIISBkry, 1896

Subfamily Dolabellina

8. Dolabella scapula (MARTYN, 1789)

Order 2. Sacoglossa

Family Caliphyllidx

9. Cyerce nigricans (PtAsr, 1866)

Family Elysiidæe

10. Placolmomchus orellatus vaN HASSELT, 1824

11. Filysia vividis (MONTAGI, 1804)

12. Elysia yaevamana nov. sp.

Order Acoda

Suborder Notaspidea

Family Pleurobranchidax

Subfamily Pleurobranchinx

13. Pleurobranchus (Oscamius) sp.

Suborder Nudibranchia

Tribe 1. Holohepatica (= Doridacea)

Family Hexabranchidx

14. Hexabranchus marginatus (QuoY and Galmar1), 1832)

Family Euphuridæ

Subfamily Euphurinæ

*15. Gymnodoris maculata STIMPSON, 185.5

16. Gymnodoris okinawae nov. sp.

17. Nembrotha luteolineata nov. sp.

Family Dorididx

Subfamily Archidoridin $x$

18. Trippa intecta (KELAART, 1858)

19. Geitodoris ohshimai nov. sp.

Subfamily Discodoridinæe

20. Discodoris yaeyamensis nov. sp.

Subfamily Asteronotinæ

21. Asteronotus cespitosus (VAN Hasselt, 1824)

*22. Halgerda graphic PASEDOW and HFDIFY, 1905

Subfamily Arginæ

23. Argus talulatus (Aвraнам, 1877) 
24. Argus cruentus (QUOY and Gaimard, 1832)

25. Argus esakii nov. sp.

Subfamily Dendrodoridinac

26. Dendrodoris (Dendrodoris) nigra (STIMPSON, 1855)

27. Dendrodoris (Dendrodoris) tuberculosa (QuoY and GAIMARI), 1832), variety

28. lendrodoris (Dendrodoris) elongata nov. sp.

Family Phyllididac

29. Phyllidia (Phyllidiella) pustulosa Cuvier, 1804

30. Phyllidia (Phyllidiella) nobilis (BFRGH, 1869)

31. Phyllidia (Phyllidia) varicosa LAMARCK, 1801

Tribe 2. Cladohepatica (= Aeolidiacea)

Family Flabellinidæ

32. Coryphella ornata RISBEC, 1928

Family Aeolidiidae

Subfamily Favorininæ

33. Pteraeolidia semperi (BERGH, 1870)

The above list contains 33 species, all but 3 of which (those without an asterisk) have been examined by the author himself.

It may be said that, as far as the Opisthobranchs known at present are concerned, the marine fauna of the Ryûkyû Islands is distinctly tropical and subtropical in constitution.

Most of the Opisthobranchs treated here have been found on dead coral reefs under blocks of moderate size, among Zosteraweeds, or in tide-pools. The author has had the advantage of observing living animals and making coloured drawings which are reproduced in this paper.

The type-specimens and examples of all the species have been deposited in the Amakusa Marine Biological Laboratory.

\section{DESCRIPTION OF THE SPECIES}

1. Cryptophthalmus smaragdinus (RüPPELL and LEUCKART, 1828)

(P1. 3, fig. 9; text.fig. 1)

Bulla smaragdina Ripiriti and Latckars, Wirbellose Thiere, 1828, p. 26, pl. 11, fig. 2, a-d. - Red Sea.

Cryptophthalmus smaragdimus Maranis, Mollusken, 1880, p. 129.-Mauritius; PILSery, TRron's manual Conch., vol. 16, 1895. pp. 37-38, pl. 6, figs. 29-36; Bergh, Srmpfr's Reisen, bk. 7, div. 4, sec. 3, 1901, pp. 235-236, pl. 19. figs. 29-38..-Tor. 


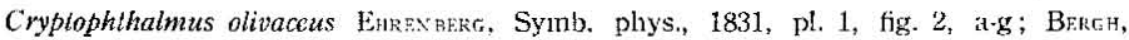
Siboga-Exped., 1905, pp. 39-41, pl. 10, figs. 9-13.-'Sula Besi, Java, Insel Kur, Gisser'; Varsstikf, Ann. Fac. Sci. Marseille, vol. 20, suppt., 1912, pp. 9-14, pl. 2, figs. 16.26 ; pl. 10, figs. 154-156.-'Tadjourah.'

Distribution in Japan: Ishigaki-shima.

The body in life is elongated, smooth, slimy, narrowed in front and swollen behind, and measures $25-30 \mathrm{~mm}$ in length (pl. 3, fig. 9). The head-shield is rather small, heart-shaped, rounded in front and narrowed behind with a median notch. Each rhinophore is represented by a row of oblique folds (about 10 in number) found at the latero-ventral side of the head-shield. The eyes are visible through the integument just in front of the rhinophores. The mantle-shield is clearly separated from the head-shield by a transverse furrow; it is elongated and produced behind into a short siphon. The mantle-aperture is very large and nearly round and

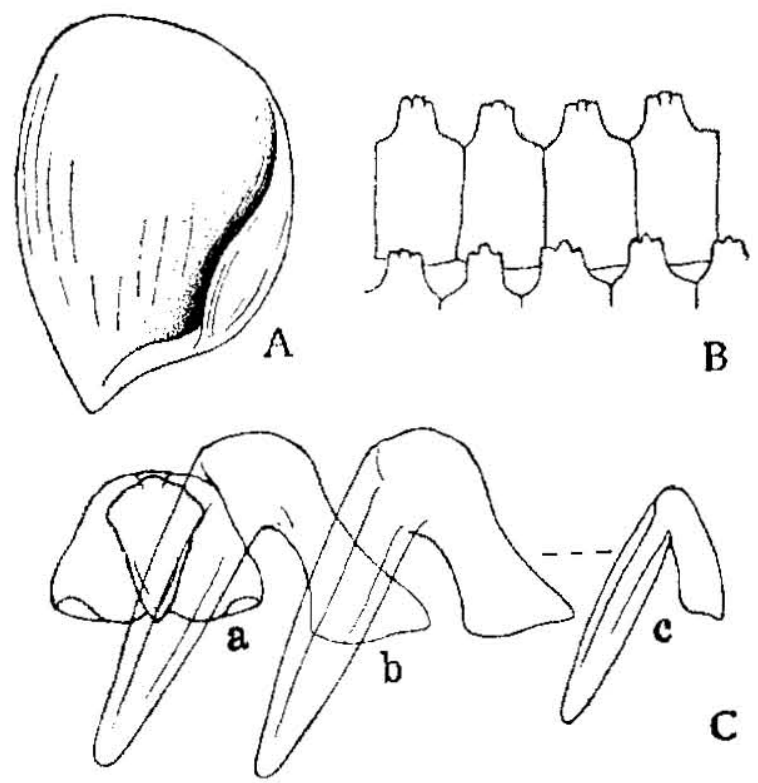

T'ext-fig. 1.-Cryptophthatmus smartgdinus. A. Shell ( 5!: B. Elements of the jaw-plate $(\times 300) ; \quad C$. A half-row of the radula $(>650)$, a. cenIral tooth, b. 1st lateral tooth, c. outermost lateral tooth.

leaves the greater part of the shell exposed. The foot is wide and the sides are continued out in fleshy parapodial lobes which stand recurved and closely applied to the lateral sides of the back. The ctenidium lies underneath the right postero-lateral end of the 
mantle-shield. The shell is small, fragilc, about $7 \mathrm{~mm}$ long, slightly involuted and formed of an upper horny and a lower calcarcous layer (text-fig. 1, A).

The coloration is of a uniform yellowish green with no markings at all.

There is a pair of jaw-plates in the pharyngeal bulb; the elements are each plate-like and divided into 3 cups at one end (textfig. $1, \mathrm{~B}$ ). The radula formula is $35 \times 15.1 .15$ (text-fig. $1, \mathrm{C}$ ); the central tooth is trapezoid with a large triangular cusp; the lateral teeth are simply hamate and smooth, and the size decreases as they approach the outer end of the row.

Locality: Kannon-zaki in Ishigaki-shima (July 11, 1934; many specimens).

\section{Aglaia cyanea (MARTENS, 1879)}

(P1. 3, fig. 8)

Doridium cyaneam Martrxs, Monatsber. Akad. Wiss. Berlin, 1879, p. 738.-Mozanbique (Last Africa).

Doridium? cyaneum Efrot, Proc. Malac. Soc. London, vol. 5, pt. 5, 1903, p. 334.-Zanzibar.

Aglaja cyanea Pulsrik, Tryns's manual Conch., vol. 16, 1895, p. 47.

Distribution in Japan: Ishigaki-shima.

The body in life is elongated, plump, soft, smooth and about $25 \mathrm{~mm}$ in length by $12 \mathrm{~mm}$ in breadth (pl. 3, fig. 8). The dorsal shield is separated by a transverse furrow into an anterior and a posterior half; the anterior is a head-shield which is oblong and free all around; the posterior is a mantle-shield (or posterior shield) and its postero-lateral ends are produced backward into two small lobes or wings. The foot is wide and truncated in front as well as behind, and the sides are extended in fleshy parapodial lobes which stand recurved at each side of the body. The ctenidium lies in a rudimentary branchial cavity under the right postero-lateral end of the mantie-shield. The shell is embedded near the posterior end of the mantle-shield, and consists of a flat spiral whorl and at minute spire; its upper layer is horny and the lower one calcareous.

The body is of a uniform glossy bluish black without markings, save for a yellowish tinge at the hindmost border of the head- 
shield. No trace of either jaw-plates or raduld is present in the: pharynx.

Locality: Kabira in Ishigaki-shima (July 26, 1934; 1 specimen, collected by Mr. MASAKI).

The present specimen is identified with Aglaia cyanea (MARTENS) which is known to be uniform blue or with small round yellow spots (MARTENS, 1879). The same species recorded by Elorot (1903) is subject to a vast range of colour-variation. One is of a uniform transparent black with a beautiful purple iridescence; others are ornamented with various markings on the blackish background.

\section{Tethys dactylomela (RANG, 1828)}

(Text-fig. 2)

Aplysici dactylomela R^si, Hist. nat. Aplysiens, 1828, p. 56, fig. 9; Exori., Bijdr. Dierk.. ed. 25, 1927 , pp. 84-90, figs. 1-3.-Curaçao, St. Croix, St. Martin, St. Jan, Water Island, West Indies, Jamaica, 'Bonaire, Loango'; Evica., Proc. Malac. Soc. London, vol. 18, pt. 4, 1929, pp. 147-151; Onnvi:r, Arktiv. f. Zool, vol. 23 a, no. 14, 1931, p. 27.-Canaries; TAki, Venus, vol. 3, no. 4, 1932, pp. 212-214.--Kii ; TAKr, ibid., vol. 3, no. 5, 1932, p. 291, fig.

Telhys dactylomela Pr.Spr., ThYon's manual Conch., vol. 16, 1895, pp. 75-76, pl. 32, figs. 16-19; Verrn.., Trans. Conn. Acad. Sci., vol. 11, pt. 1, 1901, p. 27, pl. 3. fig. 3.-Bermudas; MAcF $A R t .1 \times v$. Leland Stanford Junior Univ. Publ., Unvi. ser., no. 2 , 1909, pp. 14-37, pl. 1 , figs. 1.7 ; pl. 2, fig. 8 ; pl. 3, figs. 9-14; pl. 9. fig. 38.-Brazil.

Aplysia fimbriata Anams and Rf.:vi., Samarang, 1850, pp. 6i3-64, pl. 17, fig. 2.-Miyako. shima; PILSbik: ibid., 1895, pp. 105-106. pl. 18, figs. 20)-21. 24.

Aplysiu argus Rirpen and Lazкакт, Wirbellose Thiere, 1828, 1. 23, pl. 7. fig. 1.- Tor. Aplysia radiata Earkxisers, Symb. phys., 1831,--Tor.

Aplysia scutellata Emenusr, ibid., 1831.--Red Sca.

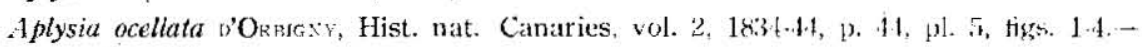
Canaries.

Syphonota viridescens Plass, Amer. Journ. Conch., vol. 4. 1868, p. 77, pl. 1). fig. 1.Kingsmille Islands.

Aplysia aequorea IIf.upre, Proc. Acad. Nat. Sci. l'hiladelphia, 1888. p. 325, pl. 16, fig. 2.-Bermudas.

Aplysia benedicti E:m, Proc. Acad. Nat. Sci. Philatelphia, 1899, p). 513-515, p. 19, figs. 2 a-2 b.-Apia (Samoa); Brren, Siboga-Experl., 1905, pp. 6-7, pl. 6i, figs. 17.26i. - Haingsisi.'

Tethys operta Bersil, Proc. Malac. Soc. London, vol. 7, 1906. p1. 51-53, figs. 1.4.South Africa.

Tethys angasi Hedt,, Proc. Linn. Soc. New South Wales, vol. 18, pt. 3, 192:3, 13, 314, pl. 33, fig. 21.-North Head (Australia).

Distribution in Japan: Ishigaki-shima, Miyako-shima, Tomioka (Amakusa) and Kii. 
The body is very large, plump, heavy, rugose, narrowed in front and swollen behind, and measures about $150 \mathrm{~mm}$ in length (text-fig. 2, A); the neck and head are long, while the tail is short and not much produced behind. The anterior tentacles are unusually large and folded (as was pointed out by ADAMS and ReEve, 1850); the rhinophores are at a short distance from them, small, conical and externally grooved on their upper portions. The parapodial lobes are wide enough to cover the visceral hump, arise from the postero-lateral sides of the rhinophores and fuse behind in the middle line. The ample mantle is oval in outline and has a small median papilla representing a mantle-aperture communicating with the shell-cavity. The posterior end of the mantle is thin, membranous and curled up in the middle line to form a short but strong excurrent siphon. The right margin of the mantle covers the ctendium and is developed into a purple gland. The common genital orifice opens immediately in front of it. The ovo-seminal groove commences at that orifice, passes forward and ends in a penial orifice lying below the right anterior tentacle. The mouth is a vertical slit situated in front of the foot which is very wide, truncated in front and narrowed behind (text-fig. 2, B).

The shell is extremely thin, nearly circular in outline, $34 \mathrm{~mm}$ long by $27 \mathrm{~mm}$ broad and moderately convex dorsad (text-fig. 2, C); it consists of an upper horny and a lower calcareous layer; the rostrum is produced, and the apex is small and distinctly involuted.

The ground-colour of the body is dark olive with paler spots and mottles. It is covered with blackish anastomosing lines in addition to a moderate number of rings; these rings are large, about $5 \mathrm{~mm}$ across, and black with radiating lines. They are about 30 in number, of which one is on the head and the rest on the lateral sides of the body including the parapodial lobes. There is a distinct black marking at the end of the tail above. The inside of the parapodial lobe bears very large round olive markings on the deep black background. The upper surface of the mantle is of an olive colour covered with pale and black mottles. The entire surface of the sole is irregularly maculated with black on an olivebrown ground-colour.

There is a pair of jaw-plates in the pharynx; the elements are very fine, rod-like, slightly curved above and tightly packed up into collar-like bands (text-fig. 2, D). 

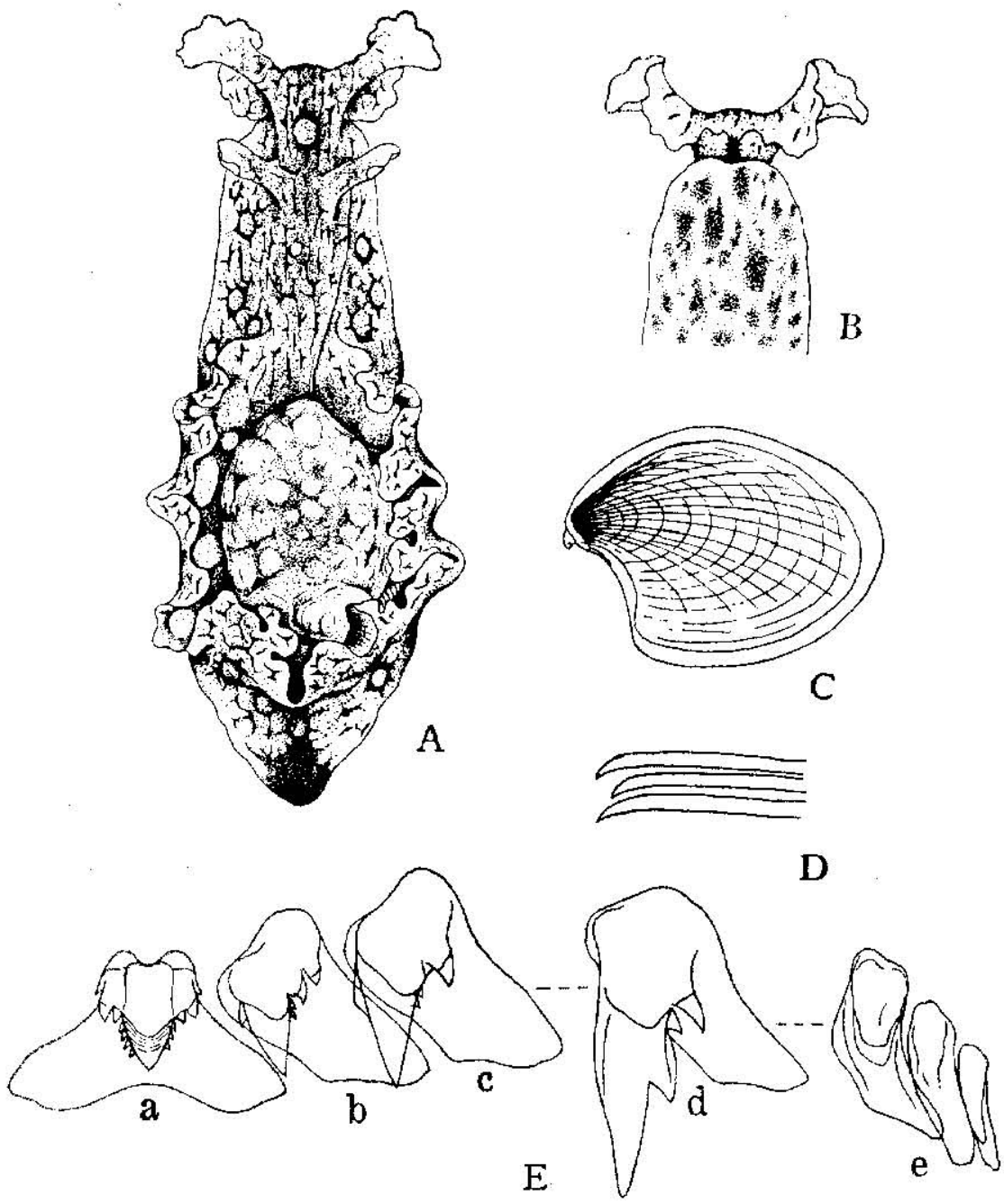

'Text-lig. 2.- Telhys dactylomcla. A. Dorsal view of the entire animal $\vdots 2$ ?) B. Ventrat view of the head and foot: C. Shell $\therefore$ 1); [n. lements of

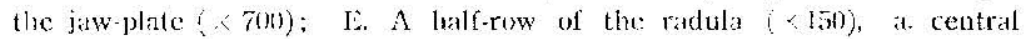
tooth, b. Ist lateral tooth, c. 2nd lateral tooth, d. 20th lateral tooth, e. vutermust tateral tecth.

The teeth of the radula are arranged in a formula $65 \times 55.1 .55$ (text-fig. 2, li). The central tooth is of a trapezoid form and has $2: 3$ sharp denticles on each side of the median cusp which is also flanked by minute denticles. The lateral teeth are all hamate, save for the outermost ones (3-4 in number) which are small and de- 
graded. The 1st lateral tooth has a large median cusp and 1-2 lateral denticles on the top, the median cusp being often flanked by minute denticles; each of the succeeding teeth has 2-3 denticles on the outer margin of the main cusp.

Locality: Ishigaki-shima (May, 1935; 1 specimen, collected by Mr. SENAHA).

The present species is especially characterized by (1) the enormous size, (2) the greenish coloration covered with large black rings and radiating as well as anastomosing black lines, (3) the parapodial lobes united behind, (4) the mantle-aperture in the form of an elevated papilla, (5) the nearly circular shell and (6) the type of the radula.

4. Tethys laevigata (STIMPSON, 1855)

Aplysia lavvigata Strnusw, Proc. Acad. Nat. Sci. Philadelphia, 1855. p. 378.--AmamiOshima.

Tothys laevigata PH.skr, Trines's manual Conch., vol. 16, 1895, p. 106.

Distribution in Japan: Amami-Ôshima.

5. Tethys hirasei nov. sp.

(I'ext-fig. 3)

Tithys sp. Hikasi, Moluskoj, 1927, p. 1465, fig. 2818--Misaki.

Distribution in Japan: Ishigaki-shima, Tomioka and Misaki.

The body in life is small, being about $25 \mathrm{~mm}$ long, and limaciform (text-fig. 3, A). The anterior tentacles are large, auriculate and situated at the antero-lateral corners of the head. The rhinophores are small, conical and grooved above. The parapodial lobes are thin and ample, with wavy margins; they arise a short distance behind the rhinophores and are freely separable throughout their length. The mantle-aperture communicating with the shellcavity is over the centre of the mantle, very small and nearly closed into a point. The mantle is produced behind in a wide lobe which is folded to form a short siphon. Its right margin covers the ctenidium and bears a purple gland which produces a purple fluid when stimulated. The ovo-seminal groove commences at the conmon genital orifice siluated just in front of the ctenidium, extends forward and ends in a penial orifice at the outer base of the right anterior tentacle. The mouth is a vertical slit situated in front of the foot, which is broad, truncated in front and narrowed behind. 

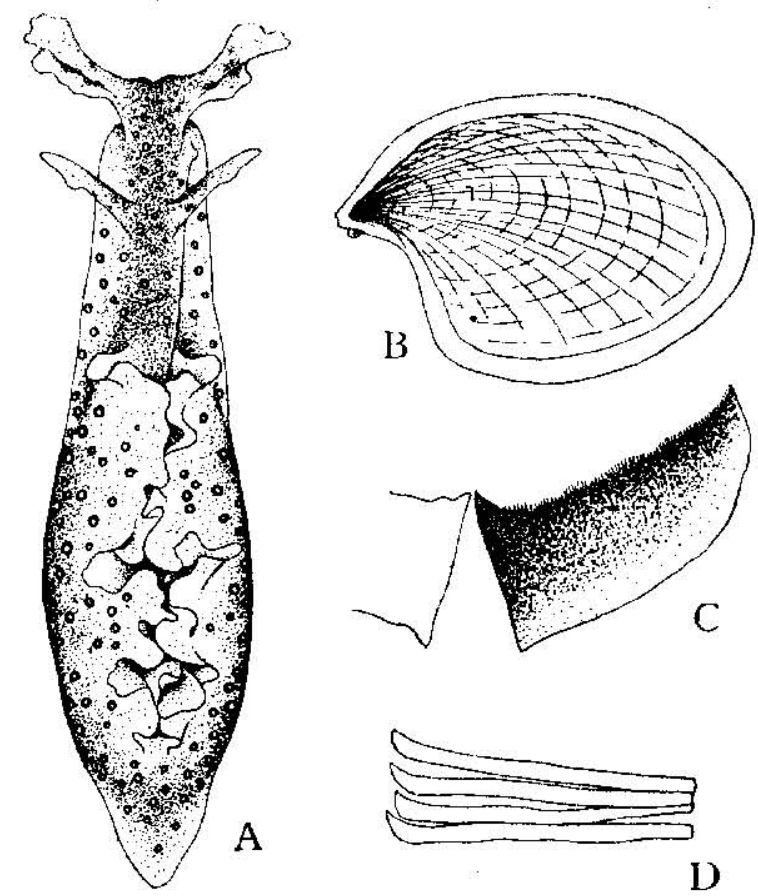

A
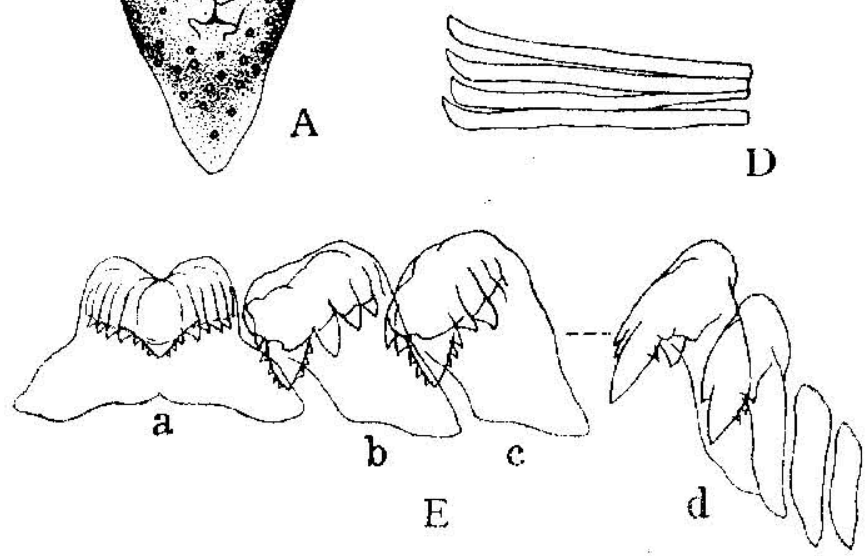

Text-lits. 3.... Tethys himasi. A. Dorsal view of the entire animal (x. 3);

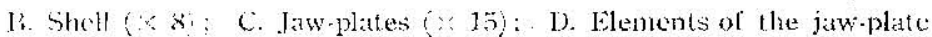

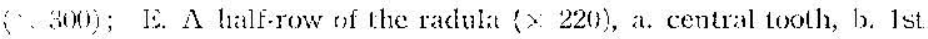
latcral tooth, s. encl fateral tooth, fl. outermost lateral teeth.

The shell is nearly circular in form, thin, small, Jeing $5 \mathrm{~mm}$ long by $3.5 \mathrm{~mm}$ broad, moderately convex dorsad, and formed of an upper horny and a lower calcareous layer (text-fig. 3, B). The rostrum is produced and rather prominent, with a coiled apex.

The ground-colour of the body is dark yellowish brown which is sparsely or concentrically spotted with opaque white; the head, sides and outer surfaces of the parapodial lobes are covered with 
an exceedingly large number of small black rings which are never accompanied by black radiating lines. The sole of the foot is of a uniform dark yellowish brown.

There are two jaw-plates in the pharynx (text-fig. 3, C-D); they are band- or collar-like, brownish, and formd of slender curved rodlets. The radula formula is $30 \times 15(-17) .1 .15(-17)$ (textfig. 3, E). The central tooth is trapezoid and has several denticles on either side of the median cusp. The lateral teeth are all hamate, save for the outermost ones which are small, degraded and simple. The inner lateral teeth have each 2.3 denticles on the lateral sides of the main cusp which is flanked by minute denticles. The succeeding lateral teeth are rather simple, with one main cusp and 1-2 lateral denticles.

Locality: Ishigaki-shima (June 29, 1934; 2 specimens, collected by Professor ESAKI).

This species is peculiar in having (1) a large number of small black rings on the body, (2) a small, nearly closed mantle-aperture, (3) two parapodial lobes which are separated behind, (4) a roughly circular shell and (5) an unmistakable radula. It is hereby recorded as new with the name Tethys hirasei, after Professor Shintarô HIRASÉ, who first noticed it. In Tomioka it grows up to $130 \mathrm{~mm}$ in length.

\section{Dolabrifera tahitensis PeAse, 1861}

(Plate, 3, fig. 2; text-fig. 4)

Dolabrifcra lahilcnsis Ptask, Proc. Zool. Soc. London. 1861, pp. 245 246.-Taliti ; Prast, Amer. Journ. Conch., vol. 4, 1868, p. 77, pl. 8, tig. 5.-Tahiti; Prtskrey, Tryns's manual Conch., vol. 16,1896 , p. 121 , pl. 34 , figs. 6-8.

Distribution in Japan: Ishigaki-shima.

The animal in life is limaciform, narrowed in front, swollen behind, and depressed, measuring about $60 \mathrm{~mm}$ in length (pl. 3, (ig. 2). The anterior tentacles are rather large and auriculate, and lic at the antero-lateral corners of the head. The rhinophores are small and auriculate, and stand a short distance behind the anterior tentacles. A pair of small eyes is immersed in the integument immediately in front of the rhinophores. The parapodial lobes are small, overlapping, separated in front and united behihd; they cover the middle portion of the dorsal slit, and an anterior and 


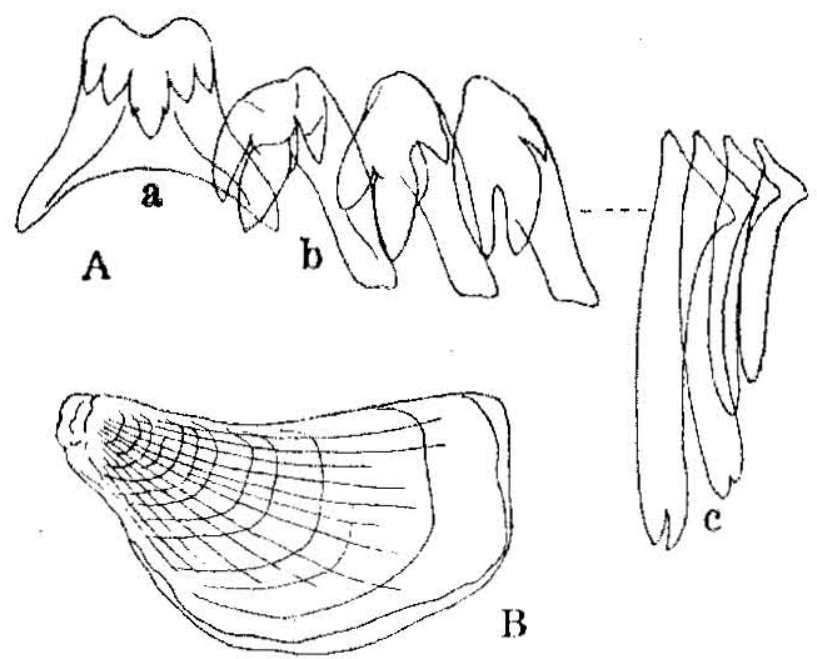

Text-fig. 4.-Dolahrifera tahitensis. $\Lambda . \Lambda$ half-row of the ratlula $(\times 300)$, a. central tooth, b. 1st lateral tooth, c. outermost lateral teeth; $B$. Shell $(x 6)$.

a posterior aperture is thus formed. The mantle is very small, contains a shell and overhangs the ctenidium on the right side. The ovo-seminal groove arises at the common genital orifice just in front of the ctenidium, and leads forward into the penial aperture at the outer base of the right anterior tentacle. The dorsal surface of the body is sparsely covered with small conical papillac which become obscure after preservation. The mouth is a vertical slit situated in front of the sole which is truncated in front and widened behind.

The shell is thin, $7 \mathrm{~mm}$ long, narrowed at the apex and widened towards the distal margin; it consists of an upper horny and a lower calcareous layer (text-fig. 4, B).

The upper surface of the body is of a grass-green colour variegated with dark green and dark brown. The sole is grassgreen covered with dark shades and white points.

The teeth of the radula are arranged in a formula $30 \times 90.1 .90$ (text-fig. 4, A). The central tooth is like an inverted $\mathrm{V}$ with the legs widened, and it has two spines on each side of the median cusp. Each of the inner lateral teeth is hamate and bicuspid at the apex, with a small outer accessory spine. The succeeding lateral teeth increase in height but are still bicuspid, and the outermost ones often become simple. 
Locality: Kannon-zaki in Ishigaki-shima (July 11, 1934; 1 specimen).

7. Notarchus (Stylncheilus) stimpsoni I'TISBRк', 1896

(PI. 2, fig. 3; text.fig. 5)

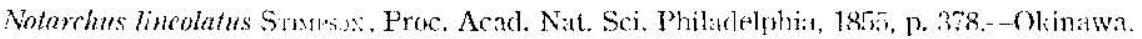
Noturches stimpsoni P'ustsy, Truin's manual Conch., vol. 16, 1896, 13. 14\%.

1)istribution in Japan: Okinawa.

The animal in life is roughly spindle-shaped, narrowed both in front and behind, and swollen in the middle of the body-length (pl. 2, fig. 3). It is very soft and small, measuring about $15 \mathrm{~mm}$ in length. The anterior tentacles are slender, simple and situated at the antero-lateral edges of the head. The rhinophores are slender and simple and lie a short distance behind the anterior tentacles. The parapodial lobes are not well developed, overlapping, separated in front and united behind ; they cover the middle portion of the dorsal slit or branchial chamber, and an anterior as well as a posterior aperture is thus formed. The branchial chamber contains a large cteniclium. The ovo-seminal groove passes between the anterior edges of the parapodial lobes, extends forward and communicates with the penial aperture at the outer base of the right anterior tentacle.

The body is nearly smooth save for the sides which are sparsely covered with small, conical, simple or branched papillx. The free margins of the parapodial lobes are smooth and not fringed. The foot is broad, truncated in front and narrowed bchind.

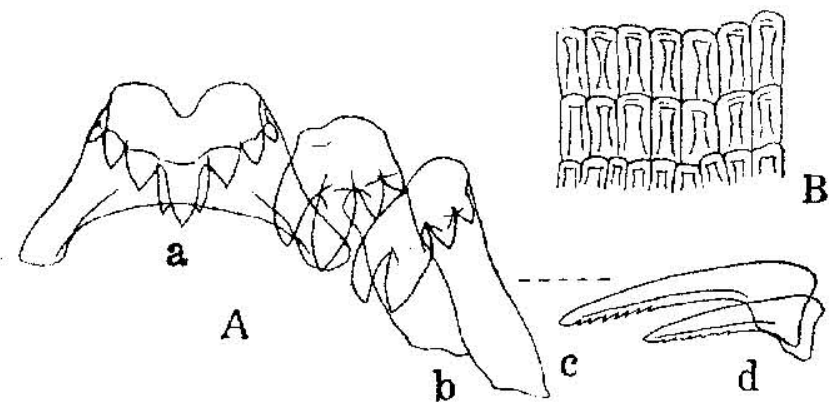

Text-fig. 5.-Notorchus stimpsoni. A. A half-row of the radula $(\times 300)$, a. central tooth, b. 1st lateral tooth, c. 2nd lateral tooth, d. outermost litteral teeth; B. Flements of the jaw-plate $\times 300 \%$.

The upper surface of the body dark yellowish brown, covered with fine, longitudinal, continuous or discontinuous lines of dark 
brown. In addition, it is ornamented with scattered yellowish brown ocelli with blue dots in the centre.

There is a pair of jaw-plates in the pharynx; their elements are flat, rectangular and arranged in rows (text-fig. 5, B). The radula formula is about $20 \times 20.1 .20$ (text-fig. 5, A). The central tooth is trapezoid with 3 spines on each side of the median cusp which is flanked by a lateral denticle. The inner (about 9) tecth are stout with 3 spines on the outer edge of the respective main blade. The succeeding outer ones, about 11 in number, become slender and hamate, with denticulate margins.

Locality: Kabira in Ishigaki-shima (July 25, 19:34; 1 specimen, collected by Professor OHshima).

In spite of some differences in the ground-colour and the size of the body, the present specimen appears to be referable to Notarchus stimpsoni PII.SBRY. It is doubtful whether the latter is different from N. lineolatus (GOULD) and N. striatus (QUOY and GAIMARD). They all agree in having (1) the black striations and nucleated spots on a greenish ground-colour and (2) the simple or branched papillac on the upper surface, though there exists a slight difference in the arrangement of these papillo.

\section{1)olabella scapula (MARTYN, 1789) \\ (Text-fig. 6)}

Patella scapula Marty, Univ. Conch., vol. 3, 1789, fig. 99---Amboina.

Dolabclla scapula Axcss, Proc. Zool. Soc. London, '1867, pp. 227-228.-Port Jackson : Tries's manual Conch., vol. 16, 1896, pp. 152-154, pl. 26, figs. $26-28$; pl. 27 , figs. 29-30; O'Diniritol, Fish. Mar. Biol. Survey, rep. 7, no. 1, 1929, pp. 31-34; pl. 3, figs. 33-35.-South Africa; Hrr.3i:, Coll. Jap. shells, 1934, pl. 120, fig. 17.

Dolabella rumphii Cuvi:k, Régne animal, vol, 2, 1817, p. 398, pl. 34, fig. 1; Barcit. Siboga-Exped., 1905, pp. 13-18, pl. 7, figs. 22-40; pl. 8. figs. 1.7.-New Guinea, 'Bima, Haingsisi, Insel Rotti' ; Varssìrt, Ann. Fac. Sci. Marseille, vol. 16, div. 2 , 1906, pp. 51-54, pl. 1. figs. 1-5.-'Djibouti. Obock' (Red Sea).

Dolabella sp. Hikssi, Dôbutsugaku Zasshi, vol. 35, nos. 417-422, 1923, pp. 43.4-442, figs. 1-10.--Okinawa, Nagasaki, Misaki, Kominato, Nabuto; Hra.s.:., Moluskoj, 1927, p. 1467, fig. 2822.-Okinawa, Nagasaki, Sôshû, Bôshû.

Distribution in Japan: Okinawa, Nagasaki, 'Tomioka, Misaki, Kominato and Nabuto.

The animal is plump and heavy, measuring over $200 \mathrm{~mm}$ in length (text-fig. 6, A); the general form is roughly conical, narrow in front and swollen behind, and the hinder end of the body is cut 
off in a posterior disk. The head bears antero-dorsally a pair of anterior tentacles which are large, grooved outwardly and auriculate in appearance. The thinophores are small, conical with a slit above and situated behind the anterior tentacles. The posterior disk is nearly circular in outline and is marked off from the rest of the body by a ridge.

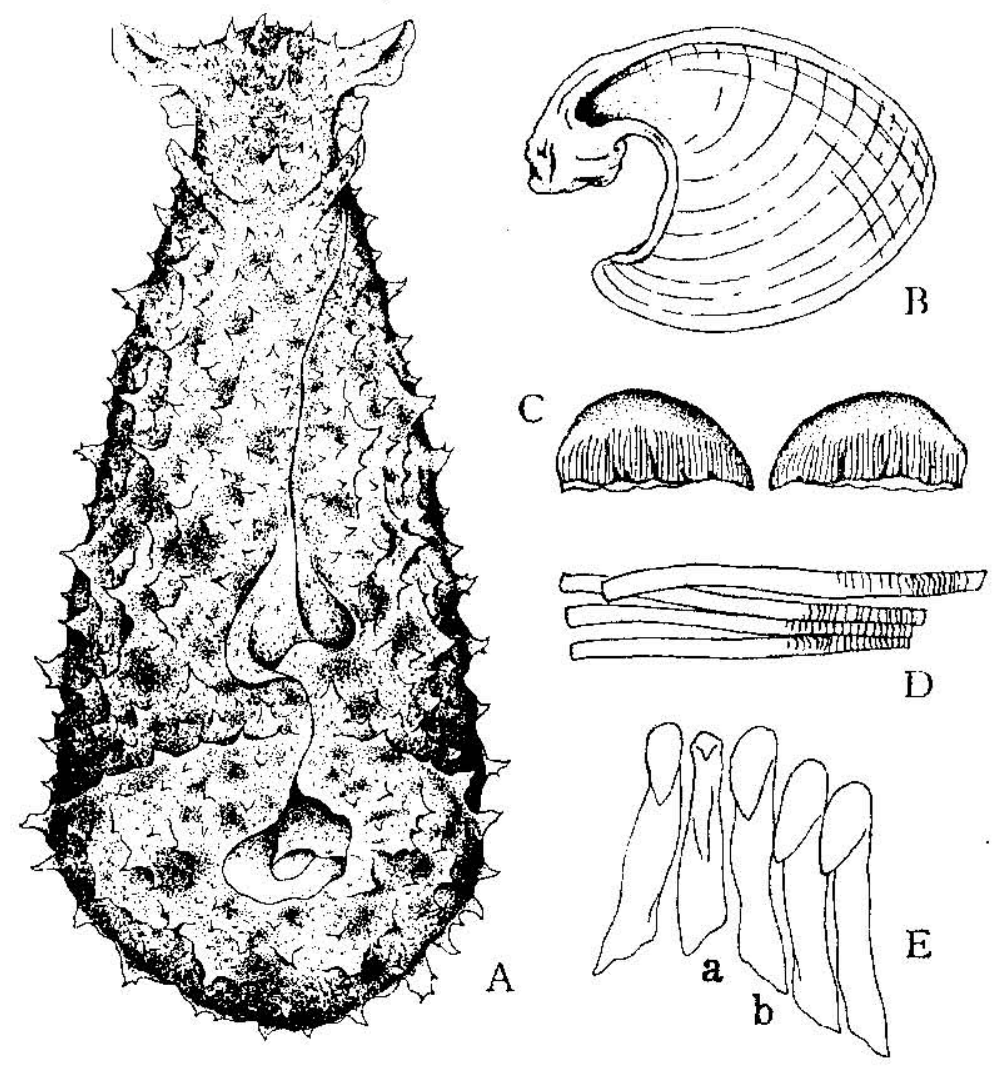

Text-fig. 6.-Dolabella scapula. A. Dorsal view of the entire animal $\left(\times \frac{1}{2}\right)$; B. Shell $(\times 1)$; C. Jatw-plates $(\times 15)$; D. Flements of the jaw-plate $(\times 115)$; F. Teeth, a. central tooth, b. innermost lateral teeth.

The parapodial lobes commence in front as two low ridges close together, with the genital groove running between them, and are completely fused behind; they partially overhang the dorsal slit, leaving an anterior and a posterior aperture. The mantle covers the shell on all surfaces and is posteriorly rolled to form an anal siphon; its right border overhanging a large ctenidium 
produces a purple fluid. The common genital orifice lies in front of the ctenidium; the ovo-seminal groove commences at that orifice and runs forward to the base of the right anterior tentacle where the penial aperture is situated. The whole dorsal and lateral surfaces of the body are covered with a large number of small or large, simple or fringed spinous warts which give a wavy appearance. There is a large wrinkled labial tentacle on each side of the mouth which is surrounded by plicac. The sole is smooth and broad, attaining the full length and width of the body.

The shell is large, solid and slightly convex dorsad (text-fig. 6, B); its upper layer is thin, horny and yellowish brown, while the lower one is thick, calcareous and whitish. The rostrum is very strong and curved inward, and the apex is indistinctly coiled. On the right side of the rostrum is a deep posterior sinus or anal notch.

The coloration of the body above is very complex, but generally it can be said that it is variegated with dark brown on a dark green ground-colour. The sole is dark orange-yellow.

There is a pair of jaw-plates inside the pharynx (text-fig. 6 , C-D); they are well developed, strong, crescentic, chestnut-brown and formed of simple chitinous rodlets which are tightly joined together. The teeth of the radula are arranged in a formula $70 \times 275.1 .275$ (text-fig. $6, \mathrm{E}$ ) ; the central tooth is small and recurved at the apex in a simple triangular blade; the lateral teeth are very numerous, hamate and simple.

Locality: Ishigaki-shima (July 26, 1934; 1 specimen, collected by Mr. Senaha).

Our knowledge of the anatomical details of Dolabella scapula (MARTYN) has been increased thanks to the work of O'DoNoGHUF (1929) on a South African specimen and we can reasonably identify the present specimen with that form, as the two agree in many respects, save for a slight difference in the form of the central tooth (O'DONOGHUE says that its apical triangular blade is provided with a number of denticles but is somewhat variable).

\section{Cyerce nigricans (PEASE, 1866)}

(Pl. 3, fig. 4; text-fig. 7)

Lobifera nigricums 13..ss:, Amer. Journ. Conch., vol. 2, 1866, p. 206,-Pacific Islands.

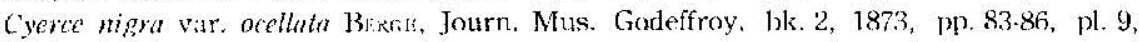


figs. 8.9 ; pl. 11, figs. 13.26; pl. 12, figs. 2-3. Samoa; BlkkH, Verh. k. k. znol.bot. Gesell. Wien, vol. 26i. 1876, pp. 750.75\%, pl. 10. figs. 10-11.-Paliau.

Distribution in Japan: Ishigaki-shima and Palau.

The body in life is elongated, about $30 \mathrm{~mm}$ in length, and consists of a small head, a short neck and an ovoid body (pl. 3, fig. 4). The antero-lateral corners of the head are produced in short pointed oral tentacles which have each an outside slit. The rhinophores are situated a short distance behind the oral tentacles, are slender, much elongated and bifurcated at the free ends. The whole upper surface of the body appears to be covered with dorsal papilla which are flat, leaf-like, deciduous and, in reality, are arranged in 23 longitudinal rows on the dorso-lateral sides, leaving the centre bare. The intestine terminates dorsally in a cylindrical papilla set just behind the neck and slightly to the right of the median line. The foot is well developed, broad and separated into two divisions, of which the anterior is the shorter and wider, and

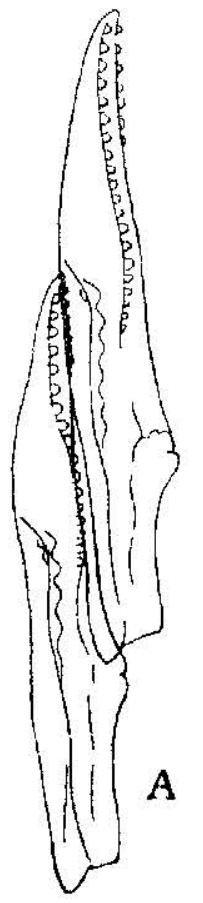

Text-fig. 7.--Cyeres nigrians. A. Teeth i $3(100$; B. Pedial sole. transversely grooved in front, and the posterior is produced behind into an obtuse point (text-fig. $7, \mathrm{~B}$ ).

The head, neck and upper side of the foot are blackish brown decorated with yellow markings and yellow broken streaks. The lateral sides are blackish brown with roundish or irregular yellow markings; the bare space of the back is blackish brown with two large longitudinal yellow streaks running parallel to each other, in addition to several roundish yellow markings behind the anal papilla. The inner and outer surfaces of the dorsal papillæ are ornamented with a submarginal yellow band and a moderate number of yellow spots. The sole of the foot is grayish white.

The teeth of the radula, 16 in num. ber (exclusive of 25 young ones in a basal sac), are arranged in the single row characteristic of the Sacoglossan mollusks (text-fig. 7, A). The radula 
formula is represented as $16 \times 0.1 .0$; each tooth is elongated with a series of about 20 denticles on each side of the large blade.

Locality: Ishigaki-shima (June 28, 1934 ; many specimens).

10. Placobranchus ocellatus van HASsEIT, 1824

(Pl. 2., fig. 1; text.fig. 8;

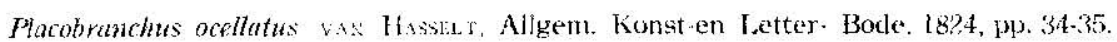

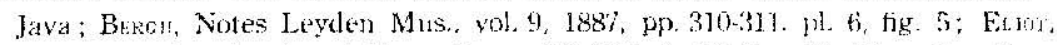
Proc Zool. Soc London, 1494, pt. 2, pp. 294.295, pl. lî, figs. 13, 13a. Kanzitar, Eisur, Journ. Conch, London, vol. 12, no. 3, 1907, p. 88.-.-Singapore.

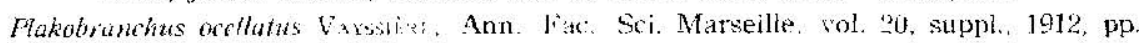
111112, pl. 1, fig. 9.-'Madjourah'; Bikt, Malat. Unters. bk. 3, 1872, pp. $14 ; \cdot 151$. pl. 19. figs. 1-13, - Sundis Sumatra. Australia.

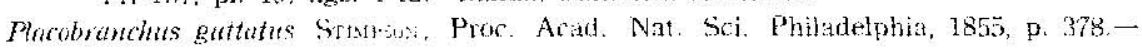
Okinawa.

Flacolsanchis gracilis $\mathrm{P}$ is (1)- - Taluiti.

\section{Distribution in Japan: Okinawa.}

The body in life is nearly cylindrical, very soft and smooth and measures about 40 $\mathrm{mm}$ in length (pl. 2, fig. 1). The head is wide and expanded in front with a median notch, and bears on its antero-lateral sides a pair of slender auriculate rhinophores. The mantle lobes are moderately wide, fleshy, separated, and recurved over the entire lateral sides of the back. The back and inner sur-

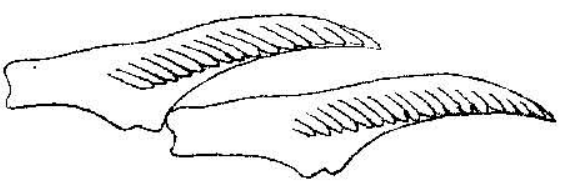

Text-fig. 8.-Placobranchus orellatus. Teeth $(\times 220)$. faces of the mantle lobes carry a large number (45) of branchial folds which radiate away from the pericardium on the anterior portion of the back. The foot is of the full length and width of the body and its antero-lateral corners are pointed.

The coloration of the body is very beautiful. The back and inner surfaces of the mantle lobes are blue-tinted. The head is yellowish gray covered with two sorts of ocelli; the one is smaller and closely-set, having a white iris and a yellow pupil, and the other, fewer in number, is larger and dark green defined by a white ring. The rhinophores are yellowish. The outer surfaces of the mantle lobes have the following two sorts of ocelli 
which cover a yellowish gray ground-colour. (1) The smaller ocelli, white with yellow centres, are exceedingly numerous, nearly hiding the ground-colour. (2) The larger ocelli have white irises and dark green pupils and are mainly arranged along the borders of the mantle lobes and the foot. The sole of the foot is dark yellow sparsely scattered with ocelli which have median black spots.

The radula consists of a single row of about 15 teeth (exclusive of the young ones in a heap) and the formula is $15 \times 0.1 .0$ (textfig. 8). The tooth is ncarly hamate with a large base and a sharp blade, the sides of which are armed with about 15-18 lateral denticles.

Locality: Sonai in Iriomote-shima (July 16, 1934; 1 specimen).

11. Elysia viridis (Montagu, 1804)

(PI. 3, fig. 6; text-fig. 9)

Laplysia viridis Mentact, Trans. Linn. Soc. London. Zool., vol. 7, 1804, pp. 76-78, pl. 7. fig. 1.-Devon (England).

Elysia viridis Bercn, Malac. Lnters., bk. 4, 1872, pp. 178-185, pl. 20, figs. 14-25; pl.21, figs. 1.13; pl. 2.4, fig. 6; Vasstikt, Ann. Mus. Hist. Nat. Marseille Zool., vol. 3 , 1888, pp. 138-142, pl. 2. fig. 6.-Marseille; Eistr, Monogr. Brit. Nud., pt. \&

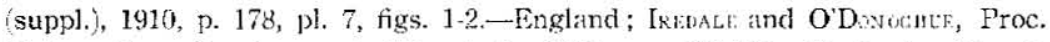
Malac. Soc. London, vol. 15, pl. 4. 1923. pp. 198-199.-England; Hirasir, Moluskoj, 1927, p. 1476, fig. 2839.--Misalki.

1)istribution in Japan: Ishigaki-shima, Tomioka, Toba and Misaki.

The limaciform body in life is $10-15 \mathrm{~mm}$ in length (pl. 3, fig. 6). The rhinophores which are slender and externally grooved lie at the antero-lateral corners of the head. The mantle lobes arise a short distance behind the rhinophores and cover the dorso-lateral surface. The pericardium is ovate, not constricted in the middle and situated on the back between the mantle lobes. The mouth is in the form of a vertical slit in front of the foot which is truncated in front and narrowed behind.

The entire surface of the body is of a dark or vivid green colour spotted with white.

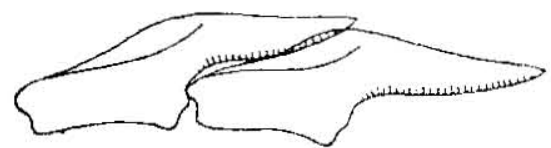

Text-fig. 9.-Elysia tridis. Teeth $(\because 200)$.
A pair of deep blue eyes is visible immediately behind the rhinophores.

The radula consists of a single row of 15 teeth (exclusive 
of the very young ones in a basal heap) and the formula is represented as $15 \times 0.1 .0$ (text-fig. 9). Each tooth is roughly hamate with a large blade and a base; the anterior border of the blade is sharp with minute serrulations, while the hinder border is grooved to receive the anterior border of the tooth behind.

Locality: Ishigaki-shima (June 28, 1934; many specimens).

12. Elysia yacyamana nov. sp.

(P1. 2, fig. 2; text-fig. 10)

Distribution in Japan: Ishigaki-shima.

The body is smooth, slender, limaciform and $50-70 \mathrm{~mm}$ in length in the living state (pl. 2, fig. 2). The rhinophores are rolled and situated at the antero-lateral corners of the head. The neck is long and the sides of the body are expanded into two :mantle lobes which are not very wide. The pericardium, when preserved, is constricted in the middle. The foot is of the full length and width of the body, widened at the antero-lateral sides and narrowed behind.

Nearly the whole surface of the body is of a green or brownish green colour; the outer and inner surfaces of the mantle lobes are covered with paler or whitish mottles. The upper portions of the rhinophores are yellow and the mantle borders are tinged with orange-yellow.

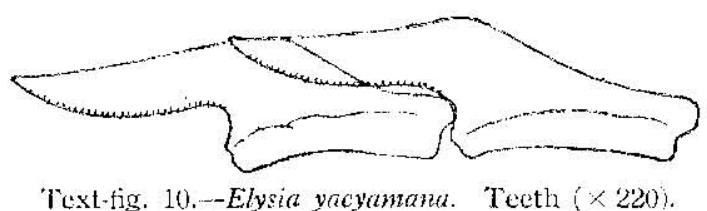

The radula has 13 teeth (exclusive of those in a basal heap) arranged in a single row and the formula is $13 \times 0.1 .0$ (text-fig. 10 ). The tooth is hamate with a large base and a pointed blade, and the latter bears minute serrulations at the antero-ventral margin.

Locality: Ishigaki-shima (June 29 and July 13, 1934; many specimens).

The present species somewhat resembles Elysia viridis (MoNTAGU) in the body-coloration and type of the radula, but is distinct because of (1) the rhinophores with yellow tips and (2) the 
mantle lobes elegantly margined with orange-yellow. It does not appear to correspond to any of the known species in the peculiar coloration or in the minutely serrulated tecth, and hence it is described here as a new species to which the name Elysia yacyamana has been given.

\section{Plourobranchus (Oscanius) sp.}

(Text-fig. 11)

Distribution in Japan: Hateruma-shima and Miyako-shima.

The specimen from Hateruma-shima is oval and convex, measuring about $45 \mathrm{~mm}$ in length in the preserved state (text-fig. 11, A). mantle is as large as the foot and its margin projects freely all the way round; it is sinuated in front; its upper surface appears to be rugose. The rhinophores are rod-like with outer slits, and contiguous at the base; they rest upon a semicircular cephalic veil
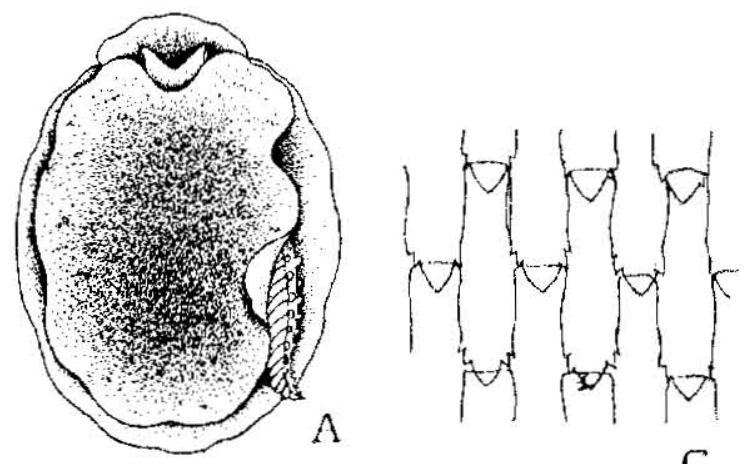

A

C

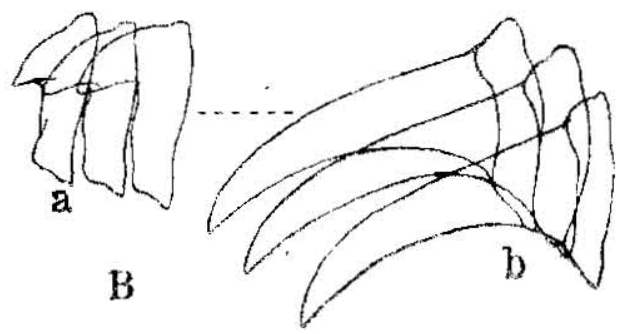

Texi-fig. 11.-Pleurobranchus sp. $\Lambda$. Dorsal view of a preserved spec1. men $(x 1)$; B. A half.row of the raduta $(x 400)$, a innermost lateral teeth, b. outermost lateral teeth; C. Elements of the jaw-plate $(\times 115)$. 
immediately below the antero-median sinus of the mantle. The ctenidium lies attached to the right side of the body and the rachis is studded with tubercles in two rows. The common genital orifice lies immediately in front of the ctenidium and the penis is guarded by a membranous appendage.

The calcified shell is small and lies concealed near the postcrior end of the mantle.

The jaw-plates arc approximately oblong, in a pair, and composed of a large number of elongated plates which are pointed at one end, where there are 1.2 lateral denticles (text-fig. 11, C). The radula formula is $73 \times 140.0 .140$ (text-fig. $11, \mathrm{~B}$ ); the teeth are all hamate and smooth, and the size increases towards the outer end of the row.

The dead specimen from Miyako-shima is smaller and measures $25 \mathrm{~mm}$ in length.

Localities: Hateruma-shima (June 27, 1934; 1 specimen, collectcd by Mr. IKEDA); Miyako-shima (I specimen, preserved in the Fourth Middle School, Miyako).

The present specimens are referred to the genus Pleurobranchus (subgenus Oscanius) because of the nembranous penial appendage and the shell posterior in position.

\section{Hexabranchus marginatus (QuoY and (Gamard), 1832)}

(Pl. 1, fig. 1 ; text-lig. 12 :

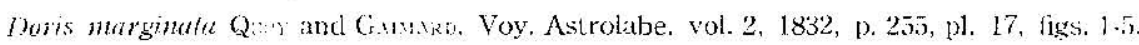

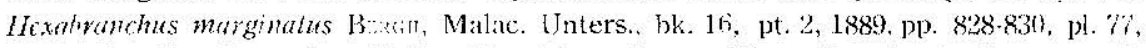
fig. 12; pl. 83. figs. 33-11.-Mauritius; Baren, Sibogra-lexped. 1905, mp. 90-91. pl. 1, tigg. 2.- 'Ost-Timor, Putu.Pasi-Tanette. Haingsisi, Süd-Insein, Gisser'; Takr. Venus, vol. 3, no. 6, 1933 , pp. 346-349, fig.--Seto: Tак, ibid., vol. 1, no. 1, 1933 , 1. 4.3; Risilc. Faune Colon. Franc., vol. 2, 1928, pp. 116-122, pl. b. fig. 4 ; pl. 2 , fig. 1 ; text-figs. 25-28.-New Caledonia.

Distribution in Japan: Garanbi (Formosa), Okinawa and Seto.

The animal in life is large, soft and of an elongate-oval shape, Ineasuring about $130 \mathrm{~mm}$ in length by $90 \mathrm{~mm}$ in breadth (p1. 1, fig. 1). The mantle is extraordinarily well-devcloped, takes the form of a thin wide flange all around, and is smooth over the surface. The rhinophores are small, perfoliated at the upper portions and retractile within pockets which have smooth margins. The branchix consist of 6 large independent tufts set in a circle 
round the anus; each tuft is divided into $3-4$ dendritic plumes; the branchial cavity is entirely absent here. The large foot is truncated and grooved in front, and narrowed behind; the mouth is in front of the foot and is guarded by a pair of oral tentacles which are large and lobe-like with folded margins (text-fig. 12, C).

The animal is very beautifu' $u^{\prime}$ the anterior and central regions of the back are pale yellow with irregular figures of a clear red colour; the mantle-flange is white ornamentcd with double bands running along the lateral and posterior margins; these bands are rather broad, zigzag in outline and clear red in colour. The rhinophores are yellowish red, the branchial plumes are brownish yellow with red veins, and the foot is tinged with yellowish red.
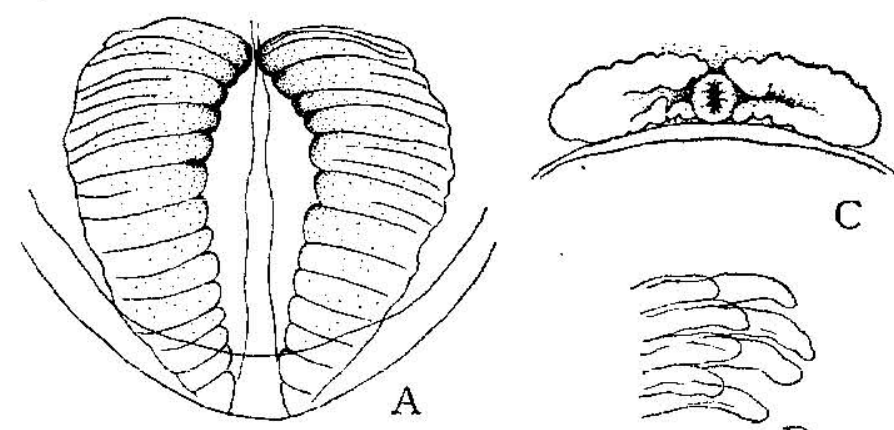

C

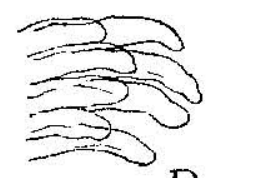

$\mathrm{D}$

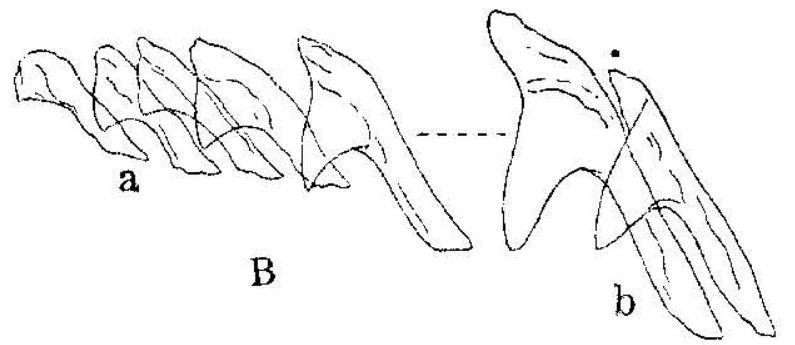

Text-fig. 12. Hexabranchus marginatus. A. Labial armatures ( $\times 6)$;

B. A half-row of the radulia $(x 115)$, a. innermost lateral teeth,

b. outermost lateral teeth; C. Oral tentacles $(\times 2)$; D. Elements of the labial armature $(\times 450)$.

The labial disk is armed with a pair of armatures (text-fig. 12, A, D); they consist of fine simple rods which are tightly joined into strong crescentic bands. The teeth of the radula are simply hamate and arranged in a formula $40 \times 75.0 .75$ (text-fig. 12, B); 
the inner lateral teeth are small and clumsy in formation, the following teeth increase in size as they pass beyond the middle of the half-row, and then they decrease in size towards the end of the row.

Locality: Kabira in Ishigaki-shima (July 25, 1934; 1 specimen).

The present species was collected by $\mathrm{Mr}$. Sadae TAKAHASI at Garanbi, the extreme southern end of Formosa, in March 1930.

15. Gymnodoris maculata STIMPSON, 1855

Gymnodoris maculata Srmpis, Proc. Acad. Nat. Sci. Philadelphia 1855, p. 379.Okinawa.

Distribution in Japan: Okinawa.

16. Gymnodoris okinawae nov. sp.

(Text-fig. 13)

Distribution in Japan: Ishigaki-shima.

The living animal is limaciform and measures about $40 \mathrm{~mm}$ in length (text-fig. 13, A). The head is indistinctly expanded to form a subquadrate veil; the body is swollen at the middle of the bodylength, where the branchiæ lie, thence gets narrower and ends in an elongated tail. The back passes over into the sides of the body without clear demarcation. The back and lateral sides are sparsely covered with indistinct tubercles. The head is loaded with a pair of small conical rhinophores which are perfoliated and retractile within sheaths. The branchial plumes are rather small, tripinnate, 9 in number, non-retractile, and arranged in a circle round the anal papilla. The foot is linear; the anterior end is obtusely truncated and the hinder end passes off into a pointed tail. The mouth lies in front of the foot and is guarded by a pair of lobe-like oral tentacles.

The ground-colour of the body is pale yellow; the upper surface is ornamented with spots and short lines of an orange-yellow colour; the perfoliated portions of the rhinophores are tinged with orange-yellow.

The teeth of the radula are all hamate and arranged in a formula $15 \times 20.0 .20$ (text-fig. $13, \mathrm{~B}$ ); the rachis is broad; the innermost lateral tooth is exceedingly small in size and somewhat 


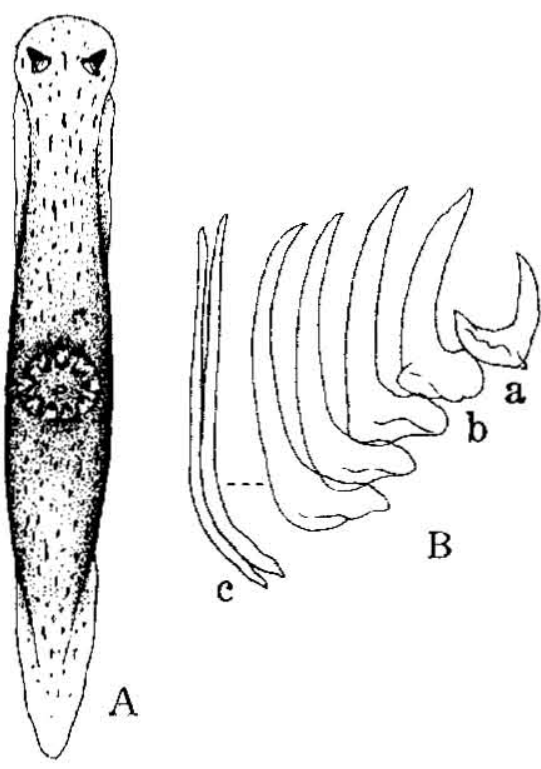

Text-figr. 13--Cimmoloris okinawac. $\Lambda$. Dorsal view of the entire animal ( 2 ); B. A half-row of the radula $\times 115, \quad$ a. 1st lateral touth, b. 2nd lateral tooth, c. outermost lateral teeth. unciform; the 2nd lateral tooth is larger with a large base and a pointed spine: the succeeding teeth increase in height as they pass outward. The hermaphrodite glands spread out in (13) thin layers on the anterior end of the liver-mass. Locality: Ishigaki-shima (June 28, 1934; 1 specimen, collected by Professor OHshima).

The present species resembles Gymnodoris alba (BERGH) in the form of the teeth, but differs from it in the body-coloration as well as in the formation of the hermaphro. dite glands.

17. Nembrotha hiteolineala nov. sp.

(P1. 3, fig. 7; text-fig. 14)

Distribution in Japan: Ishigakishima.

The body in life is limaciform, $30 \mathrm{~mm}$ long, rising from the front end to the middle, where the branchix lie, thence it gets lower again and ends in a long tail (pl. 3, fig. 7). The back is smooth and passes over into sides without line of demarcation. The head is slightly expanded and loaded with a pair of rhinophores which are conical, perfoliated at the upper portions and completely retractile within sheaths. The

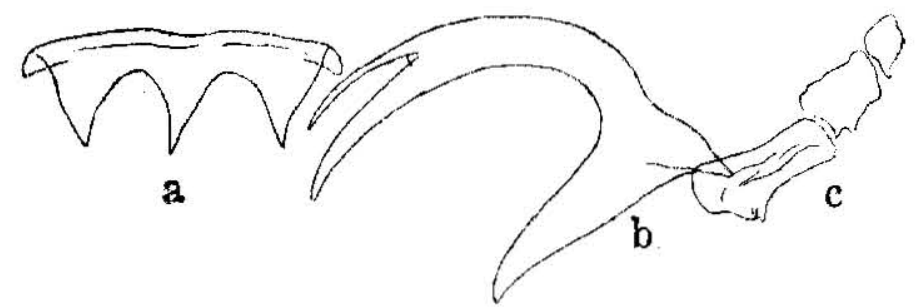

Text-fig. 14-Nembrotha luteolineata. A half-row of the radula $(\because 1201$, it. central tooth, b. 1st lateral tooth. c. succeding lateral teeth. 
non-retractile branchiæ, 3 in number, are bipinnate and arranged in a semicircle open behind. The anal papilla lies close behind the branchiæ and the genital opening is found on the right side about half way between the head and branchiæ. The foot is linear; the posterior end passes into a pointed tail, while the anterior end is truncated with obtuse corners. The mouth is in the form of a circular pore, and bears at each side a fieshy oral tentacle.

The back and sides are deep blue-black ornamented with orange lines as are shown in the figure. The rhinophores and branchial plumes are black; the sole of the foot is blue-black.

There is no labial armature in the pharynx. The radula formula is about $35 \times 3.1 .1 .1 .3$ (text-fig. 14); the central tooth is broad and slightly arcuate, and its frontal edge is furnished with 3 well. marked cusps. The 1st lateral tooth is slender and falciform, and the head is divided into two slender spines of unequal size; basally it rests upon a strong blade. The succeeding outer teeth are far smaller and scale-like.

Locality: Ishigaki-shima (June 28, 1934; 1 specimen, collected by Mr. IRISA).

There is another preserved specimen collected by Mr. SenAHA in the same locality (April 1934). It is as large as $70 \mathrm{~mm}$ in length. The back and sides are smooth and bluish black marked with dark yellow lines. The branchial plumes, 5 in number, have dark yellow lines running up into their stems. The radula formula is $40 \times 3.1 .1 .1 .3$; the character of the teeth is the same as in the preceding specimen.

Nembrotha gracilis BeRGH closely resembles the present species in the tricuspid central tooth and the bifurcated lateral tooth, but is distinguished from it in the following respects: (1) The body is blue-gray covered with yellowish white bands and tubercles; (2) the lateral teeth are only 3 in number; and (3) the 1st lateral tooth is short and stout. In the coloration of the body, N. affinis Eurot also resembles the present species, but differs from it in the subquadrate central tooth without cusps.

\section{Trippa intecta (KELAART, 1858)}

(Text-fig. 15)

Doris inlecta KetaARt, Journ. Asiatic Soc. Colombo, vol. 3, pt. 1, 1858; Kitart, Ann. Mag. Nat. Hist., ser. 3, vol. 3. 1859, p. 302.-Ceylon. 
Trippa intecti Jìr.r, Spolia zeylanica, vol. 6, 1910, pp. 83-85-Ceylon.

Trippa ornala Bsksin, Malac. Unters., bk. 12. 1877, pp. 543-546, pl. 58, tigs. 3-8.'Masinloc' Philippine Seaj; Brkgit, Malac. Unters., bk. 17, 1890, pp. 905-908, pl, 85, fig. 7; pl. 87, figs. 16-22; Brerch, Siboga-Exped., 1905, pp. 129-131, pl. 1, fig. 6; pl. 15, fig. 37.-'Sula Besi, Nusa Besi-Timor, Flores'; Er.mr, Proc. Zool. Soc. London, 1906, pt. 2, p. 658 ; Risprs. Faune Colon. Franç., vol. 2, 1928, pp. $97-99$, pl. a, fig. 4 ; pl. 3, fig. 3 ; text-fig. 18.-New Caledonia.

Distribution in Japan: Ishigaki-shima.

The animal in life is oval in outline and soft to the touch, measuring about $40 \mathrm{~mm}$ in length (text-fig. 15, A). The mantle is wide; its upper surface is ornamented with protuberances of various size; the latter are coarse in appearance and are covered with bristle-like papilloc. A well-marked mid-dorsal crest covered with the similar papillæ runs from between the rhinophores to the branchial cavity. The rhinophores are perfoliated at the upper portions and retractile within sheaths which are elevated and armed with bristlelike papiliac. The branchial plumes, 5 in number, are large, tripinnate and retractile within a cavity whose margin is recurved. The anal papilla is just behind the branchial base. The under side of the mantle is nearly smooth; the foot at its upper surface is covered with papilla. The foot is well-developed and extensible behind the mantle; its fore-end is divided into an upper and a
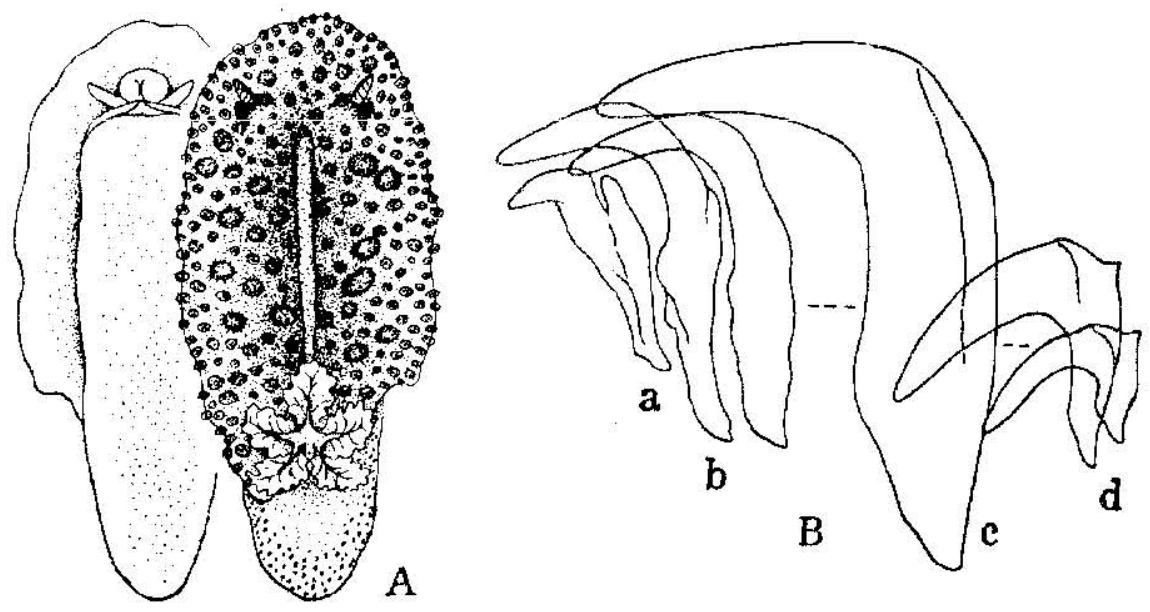

Text-lig. 15. - Trippa inceta. A. Dorsal vicw of the entire animal $(x 1.2)$; B. A halfrow of the radula $(\therefore 250)$; a 1st lateral tooth, b. 2nd lateral tooth, c. 25th Iateral tooth, d. outermost lateral teeth. (The right posterior edge of the mantle is broken.) 
lower lip and the upper lip is notched in the middle. There is a digitate oral tentacle on each side of the mouth.

The ground-colour of the body is chocolate brown; the dorsal protuberances, rhinophores, rhinophore-sheaths and branchial plumes are also tinged with deep chocolate brown; the mid-dorsal crest is whitish and conspicuous in contrast with the rest of the back.

The labial cuticle is thin without special armature. The teeth are all hamate, simple and arranged in a formula $25 \times 45.0 .45$ (text-fig. 15, B); the 1st lateral tooth is very small, the succeeding teeth increase in size as they pass outward and the outermost 2-3 become small.

Locality: Ishigaki-shima (June 29, 1934; 1 specimen).

\section{Geitodoris ohshimai nov. sp.}

(Pl. 3, fig. 5 ; text-fig. 16)

Distribution in Japan: Ishigaki-shima.

The animal in life is oval, depressed, rather soft and about $25 \mathrm{~mm}$ long by $12 \mathrm{~mm}$ broad (pl. 3, fig. 5). The mantle is wide, extending beyond the foot all around, and covered over with small

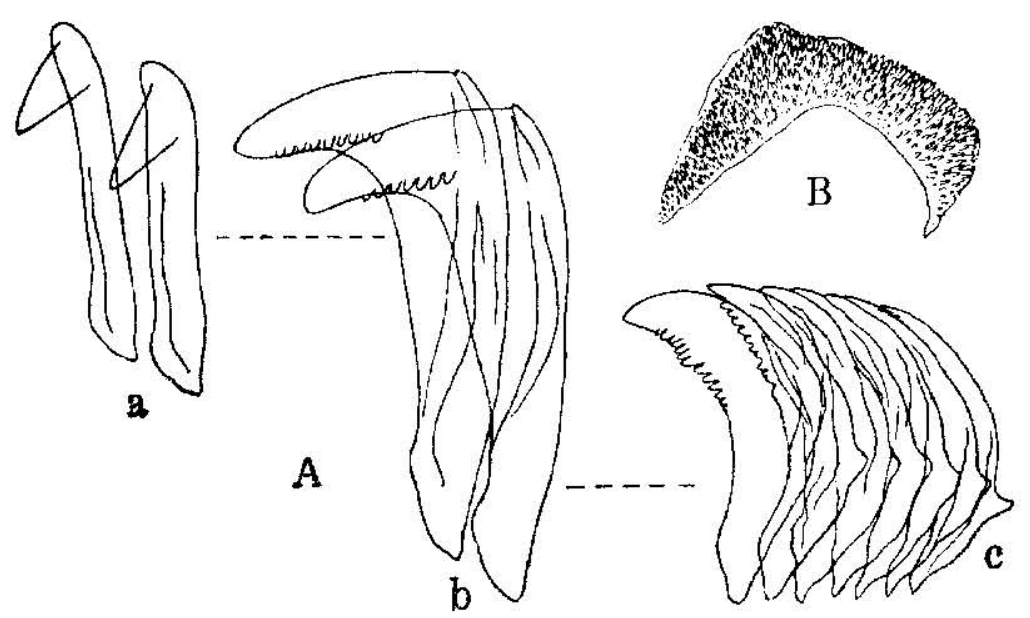

'Text-flg. 16.--Geitodoris ohshimai. A. A half-row of the radula $(\times 450)$, a. innermost lateral teeth, b. middle lateral teeth, c. marginal teeth; B. Labial armature $(\times 115)$. 
round granules. The rhinophores are perfoliated at the upper portions and retractile within sheaths; the branchial plumes, 6 in number, are arranged round the anal papilla and retractile within a cavity; the margin of the rhinophore-sheath and of the branchial cavity is guarded by small granules all around. The under surface of the body is smooth; the foot is narrow; it is rounded and grooved in front. The mouth which opens in front of the foot is provided with a small digitate oral tentacle on each side.

The back is mottled with chocolate brown on the grayish yellow background. The under side of the mantle and the sole are grayish yellow with sparsely-set chocolate dots.

There is a pair of labial armatures in the pharynx (text-fig. 16 , B); they consist of minute simple rods tightly joined into bands. The radula formula is about $20 \times 50.0 .50$ (1ext-fig. $16, A)$; the inner lateral teeth are small, the succeeding teeth increase in size as they pass outward and the marginal teeth decrease in sizc. The inner tecth, about 20 in number, are hamate and simple; the succeeding teeth are hamate with a series of $10-20$ fine dinticles on the lower edges; the marginal $7-8$ teeth are degraded, nearly spatular and closely gathered.

Locality: Kabira in Ishigaki-shima (July 25, 1934; 1 specimen, collected by Professor OHshima).

This animal is referred to the genus Geitodoris by virtue of having (1) a pair of labial armatures, (2) the hamate inner teeth and (3) the nearly spatular marginal teeth; nevertheless it is distinguishable from any of the known members of that genus bocause of the presence of denticles on the teeth.

20. Discodoris yaeyamensis nov. $\mathrm{sp}$.

(P). 3, fig. 11; text-fig. 17)

Distribution in Japan: Ishigaki-shima.

The living animal is small, flat, oval and about $25 \mathrm{~mm}$ long by $12 \mathrm{~mm}$ broad (pl. 3, fig. 11). The mantle is rather soft and wide, extending beyond the foot all around, and contains a quantity of simple spicules; its upper surface is entirely covered with fine granules. The rhinophores are perfoliated above and retractile within sheaths, whose margins are raised and entire. The branchial 
plumes, 6 in number, are small, bipinnate and completely retractile within a cavity with an entire margin. The under surface of the mantle and the foot are smooth. The foot is rather broad; it is obtusely truncated and grooved in front, and narrowed behind; the mouth bears a finger-like oral tentacle on each side.

The back is covered with well-marked chocolate mottles on the pale chocolate background; the under surface of the mantle and the foot are yellowish brown with sparsely-set chocolate mottles (text-fig. $17, \mathrm{~A}$ ). The rhinophores and branchial plumes are tinged with chocolate.
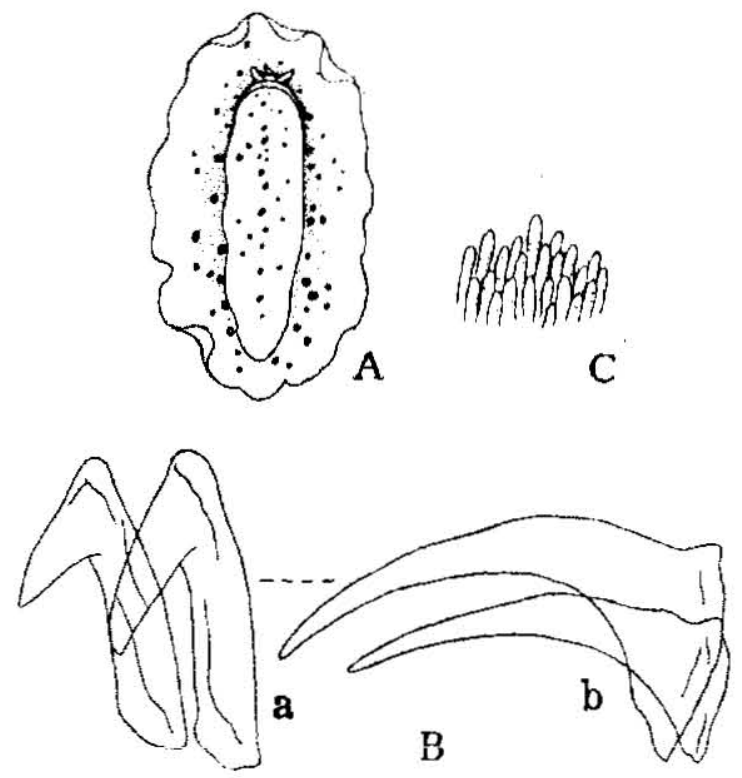

Text-fig. 17.-Discodoris yaeyamensis. A. Ventral view of the entire animal; B. A half-row of the radula $(\times 700)$, a. innermost later. a) teeth, b. outermost lateral teeth; C. Elements of the labial armature $(\times 300)$.

The lip is guarded by a pair of armatures whose elements are minute, simple and tightly gathered (text-fig. 17, C). The teeth of the radula are hamate, simple and arranged in a formula $20 \times 30.0 .30$ (text-fig. 17, B). The inner lateral teeth are small, the succeeding teeth increase in size as they pass outward and the outermost teeth are reduced in size.

Locality: Kabira in Ishigaki-shima (July 25, 1934; 1 specimen, collected by Professor OHsHima). 
The present species is very much like Halgerda japonica ELIoT in the form and coloration of the body, but is easily distinguish. able from the latter by the smooth, non-pectinate lateral teeth.

\section{Asteronotus respitosus (VAN HASsEI.T, 1824)}

(Pl. 1, fig, 2 ; text-fig. 18;

Doris cespitosa VAx Hassict, Algem. Konst-en Letter-Bode, 1824, p. 22-Java; Bfrgil, Notes Leyden Mus., vol. 9, 1887, pp. 307-308, pl. 6, fig. 9.

Asteronotus cespitosus Brcikn, Malac. Unters., bli. 17, 1890, pp. 918-921, pl. 86, figs. 7-8. -..-'Edam'; Berci!r, Siboga-lixped., 1905, pp. 141-142, pl. 1, fig. 5. - Suid-Insel bei Saleyer.'

Asteronotus hemprichii Euklakpkr, Symb. phys., 1831.-Massawa (Red Sea): Blkgh, Jalırb. Deutsch. Malakoz. Gesell., vol. 4, I877, pp. 1614.172, pl.1, figs. 1-11; pl. 2, figs. 1-2,--Red Sea; Eluvr, Proc. Zool. Soc. London, 19133, pt. 2, pp. 381 385, pl. 34, figs. 5-6.-Zanzilbar, British East Africa; libio1, Journ. Jinn. Sor Jondion, Zool., vol. 31, 1908, p. 116.-Red Sea; Ellox, Trans, Linn. Soc, Jon don, Znol., vol. 13, 1910, pp. 428-429. Ergmont (New Zealand).

Doris crescentica Culdincwwe, Trans. Iinn. Soc. London, 7ool, vol. 2, 1881, pp. 126. 127, pl. 9, figs. 6-8.-Fiery Cross Reef (China Sea), Borneo.

Distribution in Japan: Ishigaki-shima.

The animal in life is somewhat flattened, oval in outline, rather soft and leathery in consistency, and measures about $100 \mathrm{~mm}$ in length by $60 \mathrm{~mm}$ in breadth (pl. 1, fig. 2). The mantle is welldeveloped and projects considerably beyond the foot all around. The back is covered with raised protuberances but is quite smooth to the touch. Down the mid-dorsal line from between the rhinophores to the branchial cavity runs a series of $\overline{5}$ protuberances which are fused together in a well-marked ridge. There are 4 large protuberances on either side of the mid-dorsal ridge. To-

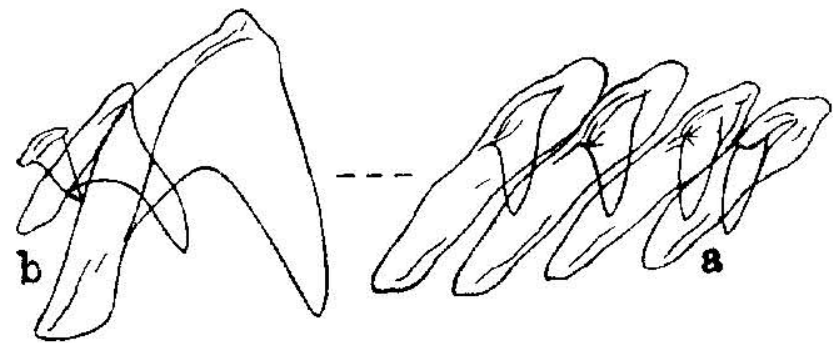

Text-fig. 18.-Asteronotus cespitosus. A half-row of the radula $(\times 115)$, a. innermost lateral teeth, b. outermost lateral teeth. 
wards the margin of the mantle there are less marked protuberances which are elongated, ridge-like, sometimes confluent, and arranged in 2-3 rows all around. The rhinophores are conical, perfoliated at the upper portions and completely retractile within sheaths, whose margins are slightly raised. The branchial plumes, 7 in number, are large, much divided and set around the anal papilla. They are completely retractile within a cavity, the margin of which is furnished with 6 valves. The foot is small, obtusely truncated in front and narrowed behind; the mouth opens in front of the foot and is provided with a finger-like oral tentacle on each side.

The back is dirty yellow shaded with brown; the protuberances are lighter and their tops are stained with dark brown; the under surface of the mantle and the foot are yellow with brown shades.

The radula formula is $40 \times 50.0 .50$ (text-fig. 18). The teeth are simply hamate and smooth and increase in size as they pass outward beyond the middle of the half-row; they decrease in size rapidly near the outer margin and the last two are much reduced.

Locality: Ishigaki-shima (June 29, 1934; 1 specimen, collected by Professor ESAKI).

The present animal is identified with Doris cespitosa van HASSELT which is cited in BERGH's work (1887) as a member of the genus Asteronotus. This species and Asteronotus hemprichii EHRENBERG reported by two well-known authorities, ELIOT (1903, 1908, 1910) and BERGH (1877), correspond so closely both in form and coloration that they may be regarded as belonging to a single species which has a wide distribution from Japan to the Red Rea.

\section{Halgerda graphica BASEDOW and HedLEY, 1905}

Halgerda graphica BASDow and Hrinf:, Trans. Roy. Soc. S. Australia, vol. 29, 1905, pp. 152-153, pl. 3, figs. 1-4.-South Australia; El.fir, Journ. Coll. Sci. Imp. Univ. 'Tôkyô, vol. 35, art. 1, 1913, pp. 11-12.-Okinawa, Otaba.

Distribution in Japan: Okinawa and Otaba.

\section{Argus tabulatus (ABRAIIAM, 1877)}

(Text-fig. 19)

Doris tabulata Ankanjam, Proc. Zool. Soc. London, 1877, p. 249, pl. 27, fig. 9.

Platydoris tabulata Elir, Trans. Linn. Soc. London, Zool., vol. 13, 1910, pp. 427-428.Indian Ocean; Estm, Journ. Coll. Sci. Imp. L'niv. Tôkyô, vol. 35, art. 1, 1913, pp. 15.17, pl. 1, fig. 5.-Misaki. 
Distribution in Japan: Ishigaki-shima, Misaki and Tateyama.

The body is ellipitical, depressed and rigid; it measures about $80 \mathrm{~mm}$ in length by $45 \mathrm{~mm}$ in breadth (text-fig. 19, A). The surface of the mantle is smooth to the touch, nevertheless it is covered with granules which are very fine and closely-set. The mantle contains rich spicules which are calcareous, spindle-shaped, and either joined into bands or arranged in a network. The rhinophores are clavate, perfoliated above and retractile within sheaths, the margins of which are elevated and crenulated. The branchial plumes, 6 in number, are much divided, arranged round the anal papilla and completely retractile within a cavity protected by 6 valves. There is a
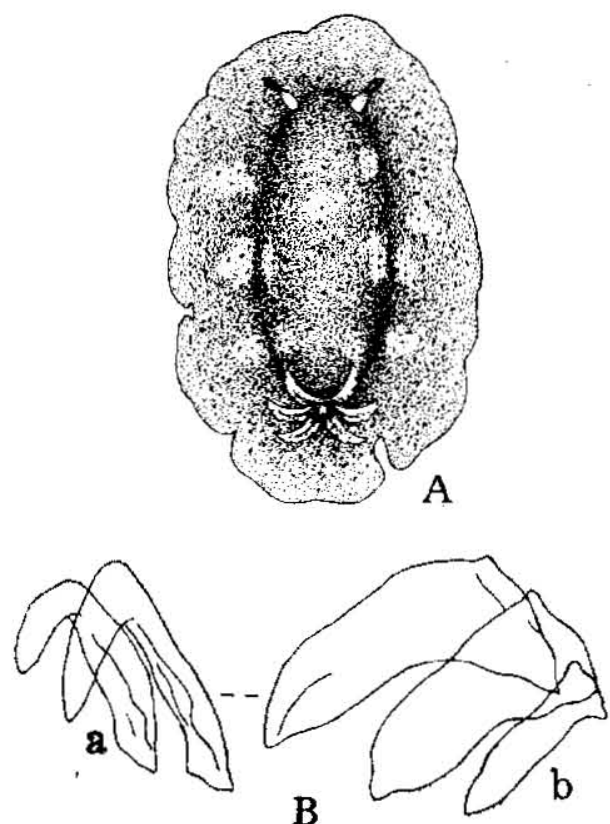

Text-fig. 19.-Argus tabulatus. A. Dorsal view of the entire animal $\left(\times \frac{5}{5}\right)$; B. A half-row of the teeth $(\times 250)$, a. innermost lateral teeth, b. outermost lateral teeth. finger-like labial tentacle on each side of the mouth which lies in front of the narrow foot.

The ground-colour of the back is yellowish white, and it is almost hidden by closelyset, very fine chocolate dots. The tops of the rhinophores and the margin of the rhinophore-sheath and of the branchial cavity are tinged with yellow. The under surface of the mantle and the sole are yellowish white; the sides of the foot are covered with dark chocolate dots and the tops of the labial tentacles are yellow-tinted.

The labial cuticle in the pharynx is thin and consists of very fine fibres. The teeth of the radula are hamate, smooth and arranged in a formula $45 \times 105.0 .105$ (textfig. 19, B).

Locality: Ishigaki-shima (June 25 and 29, 1934; 3 specimens). 


\section{Argus cruentus (QuOY and GaImARD), 1832)}

(U. 1, fig. 3 ; text-fig. 20)

Doris critenta Quy and Gamard, Voy. Astrolabe, vol. 2, 1832, p. 260, pl. 18, figs. 5.7. Platydoris cruenta Blkcil, Siboga-Exped., 1905, pp. 136-137, pl. 1, fig. 3.-'Borneo-Bank, Insei Roma, Sula Besi, Pulu-Pasi-Tanette, Insel Kabaëna'; litour, Journ. Coll. Sci. Imp. Univ. Tôkyô, vol. 35, art. 1, 1913, pp. 17-18.-Ishigaki-shima; Rısвre, Faune Colon. Franç., vol. 2. 1928, pp. 7580 , pl. a, fig. 3; pl. 1, figs. 7; pl. 2, fig. 7 ; text-fig. 9.--New Caledonia.

Distribution in Japan: Ishigaki-shima.

The body in life is elliptical, depressed and coriaccous and measures from 40 to $70 \mathrm{~mm}$ in length (pl. i, fig. 3 ). The mantle is wide with a wavy margin; it is nearly smooth but contains rich spicules which are calcareous, spindle-shaped and arranged in bundles and in a network. The rhinophores are small, clavate, perfoliated above and retractile within sheaths, the margins of which are elevated and slightly crenulated. The gills are rather small, much divided, 6 in number and arranged round the anal papilla. They are completely retractile within a branchial cavity which has a 6-lobed margin. 'The mouth opens in front of the narrow foot, and is guarded on each side by a finger-like labial tentacle.
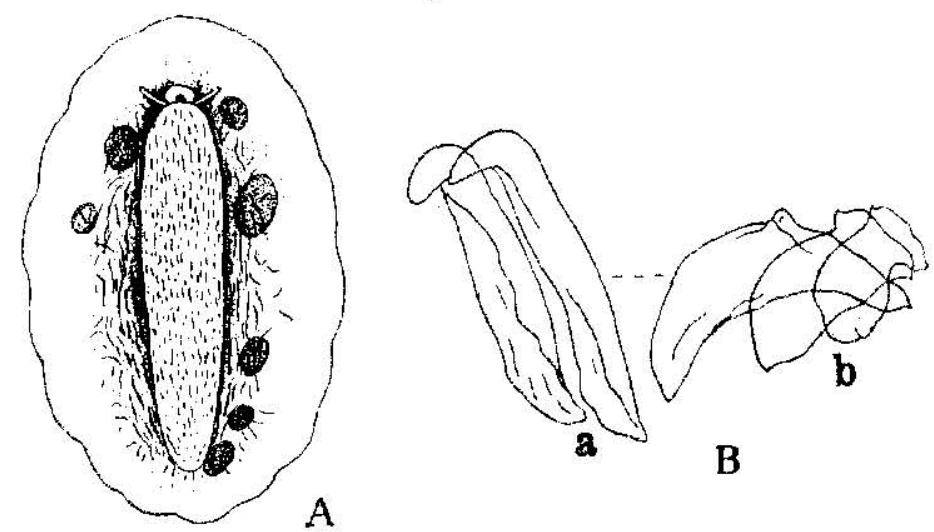

Text-fig. 20.-Argus cruentus. A. Ventral view of the entire animal;

B. A half row of the radula $(\times 250)$ it. imnermost lateral teeth,

b. outermost laterai teeth.

The ground-colour of the mantle above is pale yellow shaded with dirty brown; it is closely covered with fine, short, straight or curved lines of a chocolate colour; and it is ornamented 
with crimson blotches which are either small or large, either oval or irregular, making a marked contrast with the background. The upper portions of the rhinophores and the branchial plumes are tinged with chocolate. The lower surface of the mantle is whitish with about 7 crimson blotches (text-fig. 20, A). The lateral and ventral sides of the foot are whitish covered with chocolate lines.

The radula formula is about $50 \times 90.0 .90$ (text-fig. 20, B); the teeth are all hamate and simple, and the outermost ones are degraded.

Lorality: Ishigaki-shima (June 29 and July 13, 1934; 3 speci. mens).

\section{Argus esakii nov. sp.}

(Pl. 3, fig. 10; text-fig. 21)

Distribution in Japan: Ishigaki-shima.

The body is small, oval, depressed, coriaceous and about $25 \mathrm{~mm}$ long by $15 \mathrm{~mm}$ broad in the living state (pl. 3, fig, 10). There are rich spicules embedded in the mantle; they are rod-like and arranged either in bundles or in a network. The mantle is wide and its upper surface is covered with closely-set microscopical granules, nevertheless it is smooth to the touch. The rhinophores are small, perfoliated above and retractile within sheaths. The branchial plumes, 6 in number, are divided several times and arranged round the anal papilla; they are retractile within a branchial cavity, the margin of which is guarded by 6 valves. 'The oral tentacles are small, finger-like and situated on the lateral sides of the mouth (text-fig. 21, A). The foot is narrow.

The upper surface of the mantle is ornamented with dark chocolate mottles of various shape on a yellowish ground-colour. The margin of the mantle and that of the branchial cavity and the upper portions of the rhinophores are tinged with orange. The under side of the mantle and the foot are pale yellow; the lateral sides of the foot are mottled with dark chocolate; the margin of the foot and the tops of the labial tentacles are orange. tinted. The branchial plumes are pale yellow veined with black.

The radula formula is about $30 \times 50.0 .50$ (text fig. $21, \mathrm{~B}$ ); the outermost 3 teeth are small and somewhat irregular in shape with 
denticulate edges, while the remaining teeth are all hamate, simple and without denticles.
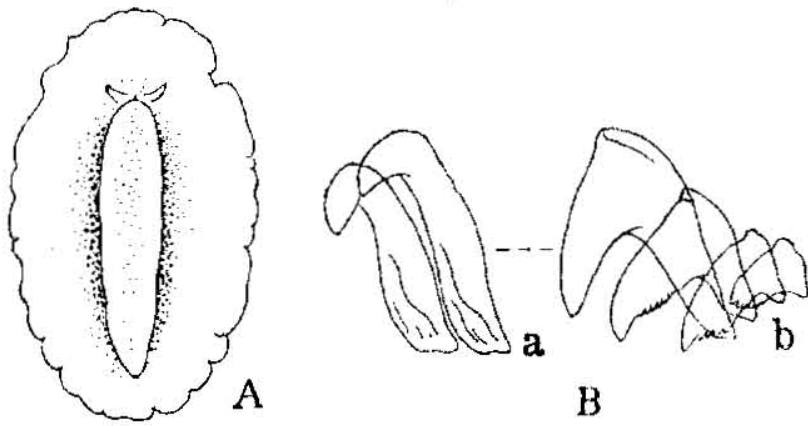

$\mathrm{B}$

Text-fig. 21-Argus esakii. A. Ventral view of the entire animal:

B. A half-row of the radula $(\times 450)$, it innermost lateral teeth,

b. outermost lateral teeth.

Locality: Kabira in Ishigaki-shima (July 25, 1934; 5 specimens).

The present species is so fine in coloration that it looks like a Glossodorid, nevertheless it is classed in the genus Argus mainly by virtue of the coriaceous integument and the type of the teeth. It differs from Argus punctatella (BERGH), a closely allied species, in the body-coloration, and in having a series of denticles on each of the outermost lateral teeth.

\section{Dendrodoris (Dendrodoris) nigra (STIMPson, 1855)}

(Pl. 3, fig. 3)

Doris nigra Stmess, Proc. Acad. Nat. Sci. Philadelphia, 1855, p. 380,-Okinawa, Kikaigra-shima.

Doridopsis nigra At.brik and Haxcick, Trans. Zool. Soc. London, vol. 5, pt. 3, 1864, pp. 128.129, pl. 31, figs. 13-16.-Madras.

Doriopsis nigra Vaysilir, Ann. Fac. Sci. Marseille, vol. 20, suppl., 1912, pp. 80-81, pl. 1, fig. 3.-' Tadjourah.'

Distribution in Japan: Okinawa and Kikai-ga-shima.

'The body in life is soft, somewhat depressed and elliptical in form (pl. 3, fig. 3); it ranges from 15 to $40 \mathrm{~mm}$ in length. The smooth mantle is thin. wide and extending beyond the foot all around. The rhinophores are small and completely retractile within sheaths with smooth circular margins; each of the former consists of a perfoliated clavus and a short cylindrical stalk. The branchial plumes are tripinnate, 6 in number, and arranged round the anal 
papilla ; they are completely retractile within a circular cavity with a smooth margin. The mouth is in the form of a small pore situated in front of the foot; it is furnished on each side with a small, partially adherent oral tentacle.

The colour of the back is black, shading off to a bluish black near the mantle-margin; it is irregularly covered with white dots, which grow abundant towards the posterior half of the back; an obscure red band surrounds the mantle at a little distance from the margin. The rhinophores are black with white tops; the branchial plumes are black. The under side of the body is uniformly stained with black.

The radula and jaw-plates are entirely wanting in the pharynx.

Lorality: Kannonzaki in Ishigakishima (July 11, 1934; 2 specimens).

\section{Dendrodoris (Dendrodoris) tuberculosa (QuoY and} GAIMARD, 1832), variety

(Pl. 1, fig. 4; text-fig. 22)

Doris carbunculosa Khanari, Journ. Asiatic Soc. Colombo, vol, 3, pt. 1, 1858; Kl. Aak1, Ann. Mag. Nat. Hist., ser. 3, vol. 3, 1859, p. 301,-Ceylon.

Doniopsis tuberatosa var. B:RБı, Malac. Unters., bk. 16, pt. 2, 1889, pp. 845-848, pl. 83, fig. 42 ; pl. 84 , figs. 5-10.-Mauritius.

Doridopsis tuberculosa var. Et.wT, Proc. Zool. Soc. London, 1906, pt. 2, pp. 661.662..Rotumah (Southern Pacific Ocean).

Distribution in Japan: Ishigaki-shima.

The living body is fairly large and of an elongate-oval shape and measures about $70 \mathrm{~mm}$ in length by $50 \mathrm{~mm}$ in breadth (pl. 1, fig. 4). The mantie is well-developed, projecting all around as a thin wavy flange, and is very soft to the touch. The back is covered with warty protuberances which give it a very uneven appearance. The large compound protuberances, over 20 in number, are on the middle of the back and are surrounded by small simple ones; the small protuberances on the flange are mostly simple, but as they pass near the border they grow ridge-like in shape. The rhinophores are stout with upper perfoliations and are completely retractile within sheaths; the margins of the latter are slightly raised, entire and not guarded by protuberances. The branchial plumes, 5 in number, are well-developed, much divided, and arranged round the anal papilla. They are completely retractile 
within a large cavity, whose margin is furnished with 5 large triangular tuberculate valves. The under side of the body is entirely smooth; the foot is large; the mouth is in the form of a small pore; the oral tentacles are very small, subconical and situated on the lateral sides of the mouth.

The ground-colour of the back is dirty yellow, shaded with dark brown; it is ornamented with a dark brown network which ramifies among the large protuberances. The rhinophores are yellowish brown; the branchial plumes are dark brown tipped with white. The under surface of the mantle and the foot are pale brown without white markings. There runs a dark streak on each side of the body between the inner margin of the

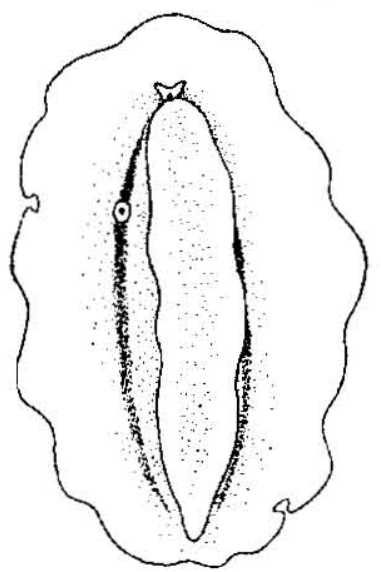

Text-fig. 22.-Dendrodoris tuberculosa. Ventral view of the entire animal. mantle and the foot (text-fig. 22); on the right side it is interrupted by the genital opening.

The pharynx is entirely destitute of the jaw.plates and radula. Locality: Ishigaki-shima (June 27, 1934; 1 specimen).

The present variety differs from Dendrodoris tuberculosa (QUOY and GAIMARD) only in not having white markings on the under side of the mantle.

\section{Dendrodoris (Dendrodoris) elonguta nov. sp.}

(Pl. 2, fig. 5; text-tig. 23)

Distribution in Japan: Ishigaki-shima.

The body in life is strikingly elongated, being $60 \mathrm{~mm}$ long by $20 \mathrm{~mm}$ broad, and the general appearance is like a Holothurian (pl. 2, fig. 5). The mantle is very soft and semi-gelatinous and projects all around as a thin wavy flange; the upper surface is sparsely covered with small subconical granules. The rhinophores are small, completely retractile within sheaths and perfoliated at the upper portions; the branchial plumes are small, 5 in number and situated near the end of the back; they are arranged round 
the anal papilla, and are completely retractile within a cavity whose entire margin is slightly raised. The under side of the body is smooth. The foot is linear, rounded in front and obtusely pointed

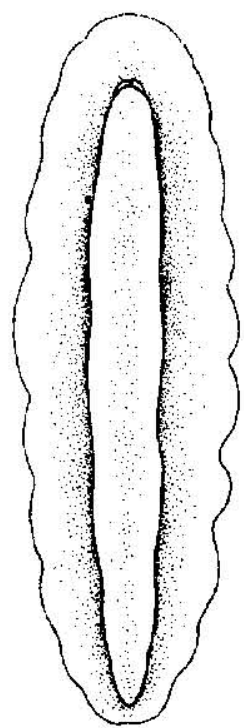

Text-fig. 23.-Dendrodoris elongata. Ventral view of the entire animal $(x 1)$. behind; the mouth is pore-like and furnished on each side with a small adherent oral tentacle (text-fig. 23).

The ground-colour of the back is a pale dirty yellow, becoming darker towards the middle, and is closely covered with dark brown mottles of various size. The perfolia. tions of the rhinophores are dark olive and the branchial plumes are stained with pale brown inside. The under side of the body is uniformly dirty yellow.

The pharynx is simple and entirely destitute of both jaw-plates and radula. The hinder end of the liver-mass is incised.

Locality: Kabira in Ishigaki-shima (July 26, 1934; 1 specimen).

The main characters by which the pres. ent species is distinguished from the previously recorded Dendrodorids are (1) the strikingly elongated form of the body, (2) the back covered with subconical granules and (3) the peculiar coloration of the body.

29. Phyllidia (Phyllidiella) pustulosa Cuvıer, 1804

(P1. 3, fig. 1)

Phyllidia pusiulosa Civık, Ann. Mus. Hist. Nat., vol. 5, 1804, p. 268, pl. 18 a, fig. 8; ELıT, Journ. Coll. Sci. Imp. Univ. Tôkyô, vol. 35, art. 1, 1913, p. 32.-Okinawashima.

Phyllidia (Phyllidiella) pustulosa Entm, Proc. Zool. Soc. London, 1904, pt. 2, p. 283.East coast of Africa.

Phyllidiella pustulosa Bkcin, Naturh. Tidsskr., ser. 3, vol. 5, 1869. pp. 154 (510).156 (512) pls. 20-24 a.-Philippine Sea ; B -Amboina; B kakl, Siboga-Exped., 1905, p. 183--Borneo-Bank. Muaras-Riff, Saleh-Bai, Lucipara-Gruppe, Kwandang-Bai, Insel Saleyer, Haingsisi, Pulu Kaniungan ketjil, Karakelang-Inseln, Insel Salibabu.'

Distribution in Japan: Okinawa. 
The animal in life is clongated oval, depressed and rather stiff to the touch; it measures about $50 \mathrm{~mm}$ in length by $20 \mathrm{~mm}$ in breadth (pl. 3, fig. 1). The upper surface of the mantle is covered with a large number of subconical tubercles; most of them are simple, but some on the mid-dorsal region are composed of 2 or 3 , rarely 4, partly fused together. The rhinophores are small, conical and entirely retractile within sheaths; the anal papilla is found in the mid-dorsal line far behind the rhinophores. The foot is rather broad, obtusely truncated in front and narrowed behind; the mouth is a tiny circular pore on each side of which lies a short subconical oral tentacle. The branchize are in the form of numerous vertical lamellæ which lie on the sides of the body between the inner margin of the mantle and the foot; they form a continuous series around the foot, interrupted at the front end by the oral tentacles, and on the right side about a quarter of the way back by the genital opening.

The ground-colour of the back is deep black; the rhinophores are black; the dorsal tubercles and anal papilla are faintly stained with dark green. The under surface of the mantle, the foot and the branchize are dark. There is neither labial armature nor radula in the pharynx.

Locality: Ishigaki-shima (June 25, 1934; 1 specimen, collected by Professor ESAKI).

\section{Phyllidia (Phyllidiella) nobilis (BERGH, 1869)}

(Text.fig. 24)

Phylidiella nobilis Bkng!t, Naturh. Tidsskr., ser. 3, vol. 5, 1869, pp. $156(512)-157$ i51:3), pl. 24 b.- Burias, Luzon.'

Phyllidia nobilis Elıt, Journ. Coll. Sci. Innp. Univ. Tôkyô, vol. 35, art. 1, 1913, p. 32. -Ogasawara-shotô.

Distribution in Japan: Ishigaki-shima, Kii and Ogasawara-shotô (= Bonin Islands).

The preserved animal is of an elongated oval shape, with the greatest width in the middle of the body-length (text-fig. 24); it measures about $35 \mathrm{~mm}$ in length by $20 \mathrm{~mm}$ in breadth. The back is covered with many tubercles arranged in the following manner: Around the extreme margin is a single row of sparsely-set tubercles 
which are mostly simple, rarely compound. The rest of the dorsal tubercles are larger and lic in irregular quincunx.like lumps, each lump being formed of 5.16, partly fused together. The lumps are arranged in 3 longitudinal rows down the centre and in one marginal row inside the margin. The rhinophores are completely retractile

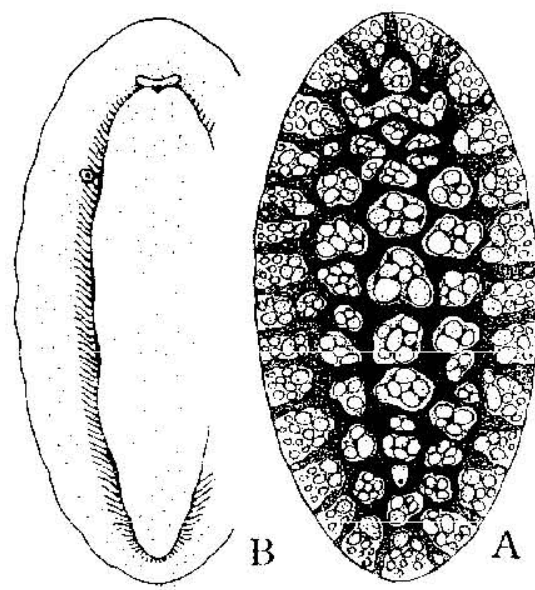

Text-4ig. 24.-Phyllidia nobilis. A. Dor. sal vicw of a preserved specimen $(\times 1.7)$; J. Ventral view of the sance. within deep sheaths; the anal papilla lies in the mid-dorsal line about $8 \mathrm{~mm}$ from the hinder end of the back. The front end of the foot is round with a median notch and the hinder end is bluntly pointed. The mouth is pore-like and bears two labial tentacles with fused bases. The branchial lamel$1 x$ are arranged all around the foot except at the places where the labial tentacles and genital opening lie.

The dorsal tubercles and lumps are grayish and the background is decp black; the under side of the mantle, the branchioe and the sole are all pale black.

Locality: Ishigaki-shima (1 specimen, collected by Mr. HАzAMA).

\section{Phyllidia (Phyllidia) varicosa LAMARCK, $180 \mathrm{j}$}

(1ext-fig. 25)

Phyllida varicosa l.1:1nack, Syst. atlim. sitns vertebres, 1801. 13, 66; Birgh, Naturh, Tidsskr., ser. 3 , vol. 5, 1869, pp. $143(499)-148(504)$, pls. $14-18$ a; Esmt. Proc. Zool. Soc. London, 1904, pt. 2, p1). 281-282.--Zanzibar, Mainlancì of East Africa : Bґкон, Siboga-Exped, 1905, p. 180.- Insel Saleyer, Pulu Kaniungan ketjil, Saleh-Bai, Borneo-Bank, Insel Rotti, Insel Gebé, Haingsisi, Insel Karakelang, Roma, Makassar'; Er.rit, Journ. Lintr. Soc. London, Zool., vol, 31, 1908, p. 120. --Red Sea; Esmo, Trans. Linn. Sos. London, Zool, vol. 13, 1910, p. 435. Salmon, Aldabra (Indian Ocean); Varssi:rs: Anu. Fac. Sci. Marseille, vol. 20, suppl., 1912, pp. 84-85.-'Tadjourah.'

Phyllidia varicosa var. quadrilineata Bakcir, ibid., 1905, p. 181, pl. 12, 1igs. 11-12.-...'GunongApi.'

1) istribution in Japan: Ishigaki-shima.

The preserved animal is rather large, flat, of an elogate-oval 
form and about $60 \mathrm{~mm}$ long by $35 \mathrm{~mm}$ broad (text-fig. 25). The mantle is soft and wide, extending beyond the foot all around. The back is covered with well-marked tubercles which are mostly simple, rarely compound and more or less fused to form ridges. Three longitudinal ridges containing 10-11 tubercles run down the middle of the back. Of these, the mid-dorsal one arises between the rhinophores and leads to the front of the anal papilla, while the dorso-lateral ones arise behind the rhinophores, run parallel to the mid-dorsal one, and end in front of the anal papilla. Around and more or less at right angles to the margin are about 30 short ridges running inward; they consist of 8-10 tubercles which decrease in size outward. The rhinophores are completely retractile within sheaths which are now represented by two small papillæe situated in front of the dorsolateral ridges, and the anus opens on a small papilla just behind the union of these ridges.

The under side of the mantle is smooth with a latticework. The foot is well developed; the anterior end is round with a median notch and the posterior end is narrowed; its dorsal surface is closely covered with fine papillac. The mouth is in the form of a small pore, at the sides and front of which are two subconical oral tentacles with fused bases. The branchial lamella are arranged in a continuous band around

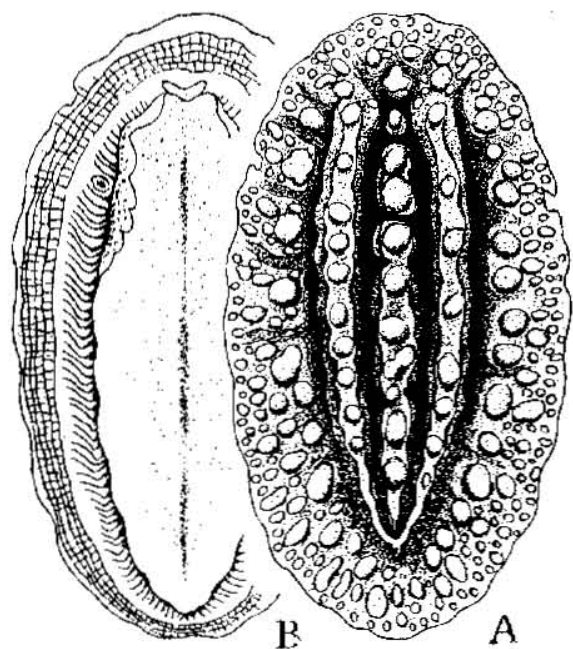

Text-fig. 25.-Phyllidite verricosa. A. Doral view of a preserved specimen $1:$ B. Ventral view of the same. the foot, interrupted as usual by the oral tentacles and genital opening.

The colour has nearly gone; the ground-colour of the back is dark brown, forming irregular streaks which run among the ashy ridges; the under side of the mantle, the branchial lamellæ and the foot are ashy; the sole has a median dark longitudinal streak.

The pharynx is simple and lacks both jaw-plates and radula.

Locality: Ishigaki-shima (1 specimen, collected by Mr. HAzAMA). 
32. Coryphella ornata RisBEc, 1928

(P1. 2, fig. 4: text fig. 26)

Coryphella ornata Ressec, Faune Colon. Franç., vol. 2, 1928, pp. 266-268, pl. 9, fig. 6 ; pl. 11, tig. 1, text.fig. 89.--New Caledonia.

Distribution in Japan: Ishigaki-shima.

The living animal measures about $10 \mathrm{~mm}$ in length (pl. 2, fig. 4). The oral tentacles are strikingly elongated and lie at the antero-lateral ends of the head. The rhinophores are club-shaped, non-retractile and perfoliated at the upper portions. The branchial papillax are long, fusiform and arranged in 6-7 groups on each side of the back; the anterior 4.5 groups contain each two papillæe and the succeeding two groups only one papilla. The foot is linear and its antero-lateral corners are produced into horns.
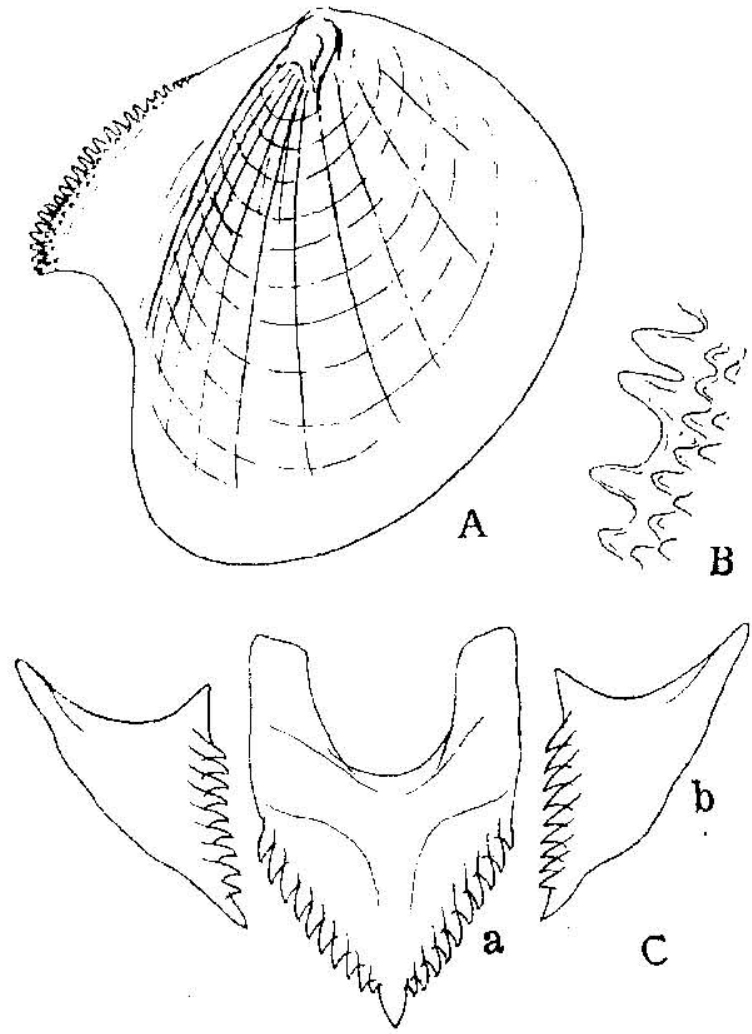

Text-fig. 26.-Coryphella ornata. A. Jaw-plate $(x 115 ;$; B. Denticles on the masticatory process $(650 ;$ C. A row of the ratula $(\times 650)$, a. central tooth, b. lateral tooth. 
The body is palc yellowish white; the rhinophores and branchial papillæ have an orange yellow ring near the respective top.

The jaw-plates are shell-shaped (text-fig. 26, A-B); the masti. catory process is large though short, and is covered with several rows of small blunt denticles.

The radula formula is $17 \times 1.1 .1$ (text-fig. $26, \mathrm{C})$. The central tooth consists of a somewhat rectangular horseshoe-shaped base with a round posterior, and a triangular anterior margin; its apex is marked by a median cusp on each side of which is a series of about 10 curved denticles. The lateral tooth is in the form of a roughly triangular plate; the inner margin carries a series of about 9 denticles.

Locality: Ishigaki-shima (July 14, 1934; 1 specimen, collected by Professor OHSHIMA).

The present specimen agrees with Coryphella ornata RISBEC in many respects, external form, body-coloration and radiula, except that it has several rows of denticles on the jaw-plates.

\section{Pteraeolidia semperi (BERGH, 1870)}

Ilabelina semperi Bergn, Malac. Unters. bk. 1, 1870, pp. 18-30, pl. 2; pl. 3, figs. 1-15. -'Panglao' (Philippine Sea).

Picracolidia semperi BERGH, Verh. k. k. zool-bot. Gesell. Wien, vol. 25, 1875, p. 652; El.ror, Journ. Coll. Sci. Imp. Univ. Tôkyô, vol. 35, art. 1, 1913, p. 44.-Ogasawara-shotô, Misaki, Sagami.

Distribution in Japan: Okinawa-shima, Misaki, Sagami, Tateyama, Ogasawara-shotô (= Bonin Islands) and Palau.

Locality: Okinawa-shima (August 1930; 1 specimen, preserved in the Third Middle School, Nago).

The Amakusa Marine Biological Laboratory, Tomioka, Kumamoto-ken, Japun.

\section{POSTSCRIPT}

The following Dorids are also recorded by STIMPson in "Descriptions of some of the new marine Invertebrata from the Chinese and Japanese seas." Proc. Acad. Nat. Sci. Pailadelphia, 1855.

1. Doris olivacea, from Okinawa.

2. Doris rogersii. from Kikai-ga-shima.

3. Doris latens, from Okinawa.

The taxonomy of these species will be discussed later. 


\section{BIBLIOGRAPHY}

The asterisk (*) indicates the paper which was not accessible to the atuthor.

Arraham, P. S. 1877 Revision of the anthobranchiate Nudibranchiate Mollusca, will descriptions or notices of forty-one hitherto undescribed species. Proc. Zuol. Soc. London.

Aosis, A. and L. Rseve 1850 Zoology of the voyage of H.M.S. Samarang. Molluscid.

Atol: J. and A. Haxeres 1864 Notice of a collection of Nudibranchiate Mollusca made in India by Was.TiR EL.IIT, Esq., with descrptions of several new genera and species. Trans. Zool. Soc. London, vol. 5, pt. 3.

Aricis, G. F. 1867 A list of species of marine Mollusca found in Port Jackson Harbour, New South Wales, and on the adjacent coasts, with notes on their habits, etc. Proc. Zool. Soc. London.

BARA, K. 1930 Studies on Japanese Nudibranchs. 2. Venus, vol. 2, no. 2.

Baspon, $H$. and $\mathrm{C}_{\mathrm{H}}$. Him.j 1905 South Australian Nudibranchs, and an enumeration of the known Australian species. Trans. Roy. Soc. S. Australia, vol. 29.

B.kcn, R. 1869 Bidrag til en monographi af Phyllidierne. Niturh. Tidsskr., ser. 3. vol. 5.

-- 1870 Malacologische Lntersuchungen, bk. 1.

--- 1872 Malacologische Untersuchungen, bks. 3, 4.

- 1873 Neue Nacktschnecken der Südsee. 1. Journ. Mus. Godeflroy, bk. 2.

-...- 1875 Neue Beiträge zur Kenntnis der Phyllidiaden. Verh. k. k. zool.bot. Gescll. Wien, vol. 25.

1875, 1876 Beiträge zur Kenntnis der Aeolidiaden. 3, 4. Verl. k. k. zool.-bot. Gesell. Wien, vols. 25, 26.

-..- 1877 Malacologische Untersuchungen, bks. 11, 12.

1877 Über das Geschlecht Asteronotus Errfanfrer. Jaturb. Deutsch. Malakoz. Gesell., vol. 4.

-... 1878 Neue Nacktschnecken der Sucksee. 4. Journ. Mus. Godeffroy, bk. 14.

- 1887 Die vax Hasst.t'schen Nudibranchien. Notes Leyden Mus., vol. 9.

-..- 1889 Malacologische Untersuchungen, bk. 16 pt. 2. Nudibranchiata vom Mecre der Insel Mauritius.

1890 Malacologische Untersuchungen, bk. 17.

… 1898 Die Opisthobranchice der Sammlung Pi.Arf. Zool. Jahrb., Suppl., vol. 4. Fauna Chilensis, vol. 1.

1901 Bullacea. Stmpez's Reisen im Archipel der Philippinen, vol. 7, div. 4, sec. 3.

1904 Nudibranchiata, 'Tectibranchiata-Pectibranchiat:1, SFsfp.s's Reisen im Archipel der Philippinen, vol. 9, pt. 6, no. 1.

...... 1905 Die Opisthobranchiata der Siboga-Expeditie. Siboga-Exped., monogr. 50.

BuRnf, R. H. 1906 Notes on the anatomy of South African Aplysiida, with descriptions of two new species. Proc. Malac. Soc. London, vol. 7.

CLEssIX, S. 1899 Die Familie der Aplysiidæ. Systematisches Conclyylien-Cabinet von Martint und Chamitz.

Coldixgwoon, C. 1881 On some new species of Nudibranchiate Mollusca from the Eastern seas. Trans. Linn. Soc. London, Zool., vol. 2. 
*Cuvar, G. L. 1804 Memoire sur la Phyllidie et le Pleurobranche. Ann. Mus. Hist. Nat., vol. 5 .

*..._- 1817 Le règne animal, distribué d'après son organisation, pour servir de base à l'bistoire naturelle des animaux et d'introduction à l'anatomie comparée, vol. 2 .

Deзная:s, M. G. P. 1857 Note sur différents mollusques de la Guadeloupe. Journ. Conchyl., Paris, vol. 6.

*Eurfarfora, C. G. 1831 Symbolie physice, animalia evertebrata exclusis insectis percensuit Dr. C. G. Lihrinelare.

F. LIuT, C. 1849 Notes on Tectibranchs and naked Mollusks from Samoa. Proc, Acad. Nat. Sci. Philadelphia.

1903 On some Nudibranchs from East Africa and Zanzibar. 2, 3. Proc. Zool. Sioc. Iondon, pts. $1,2$.

1903 Notes on some new or little-known members of the family Doridiida. Proc. Malac. Soc. London, vol. 5, pt. 5 .

-.- 1904 On some Nudibranchs from East Africa and Zanzibar. 5, 6. Proc. Zool. Sor. London, pt. 2.

1906 On the Nudibranchs of the Southern Indiat and Ceylon, with special reference to the drawings by Kl:LAAR and the collections belonging to ALDl:R and Haxiock preserved in the Hancock Museum at Newcastle on-Tyne. Proc. 7.ool. Soc. London, pt. 2

-... 1907 Nudibranchs from the Indo-Pacific. 3. Journ. C.nch., London, vol, 12, no. 3.

...- 1908 Reports on the Marine Biology of the Sudanese Red Sea. 11. Notes on a collection of Nudibranchs from the Red Sea. Journ. Linn. Soc. London, Zool., vol. 31 .

1910 Notes on a collection of Nudibranchs from Ceylon. Spolia Zeylanica, vol. 6 .

-..... 1910 A monograph of the British Nudibranchiate Mollusca : with figures of the species, pt. 8 (suppl.)

1910 Nudibranchs collected by Mr. Sranisy Gardines from the Indian Ocean in H.Mi.S. Seaiark. Trans. Linn. Soc. London, Zool., vol. 13.

Exct.., H. 1927 Westindische Opisthobranchiate Mollusken. Bijdr. Dierk., ed. 25.

- 1929 Aplysia dactylomcla RANa, at circumtropic species. Proc. Malac. Soc. Lon. don, vol. 18 , pt. 4.

Gutr. A. A. 1852 Mollusca and shetls of the Lnited States Exploring Expedition cluring the years 1838.42 under the command of ChakLlss WILKEs, vol. 12.

"vas Hassi:I, J. C. 1824 Uittreksel uit eenen Brief van Dr. J. C. VAX HAsseLT ann Prof. van Swindren. Allgem. Konst-en Letter-Bode.

Ifedily, C. 1923 Studies on Australian Mollusca. 14. Proc. Ijinn. Soc. New South Wales, vol. 48 , pt. 3 .

"HFilskis, A. 1888 Contribution to the Natural History of the Bermuda Islands. Proc. Acad. Nat. Sci. Philadelphia.

Hikssí, S. 1923 Anatomy of Dolabella. Dôbutsugaku Zasshi, vol. 35, nos. 417-422. 1927 Figuraro de Japanaj Bestoj, Moluskoj.

..... 1934 A collection of Japanese shells with illustrations in natural colours.

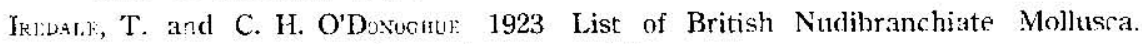
Proc. Malac, Soc. Loncton, vol. 15, pts. 4.5. 
KFLAAKT, E. F. 1858 Descriptions of new and little-known species of Ceylon Nudibranchiate Mollusks and Zoophytes. Journ. Asiatic Soc. Colombo, vol. 3, pt. 1.

.. 1859 Descriptions of new and little-known species of Cevlonese Nudibrachiate Mollusks. Ann. Mag. Nat. Hist., ser. 3, vol. 3.

Lanarck, J. B, 1801 Système des animaux sans vertébrés.

MacFarland, F. M. 1909 The Opisthobranchiate Mollusca of the BranNFr-AaAsir expedition to Brazil. Leland Stanford Junior Univ. Publ., Univ. ser., no. 2.

Martins, E. I. 1879 Übersicht der von W. Petfrs von 1843 bis 1847 in Mossam bique gesammelten Mollusken. Monatsber. Akad. Wiss. Berlin.

1880 Die Mollusken der Maskarenen und Seychellen auf Grund der von Professor Karl Müzus daselbst gesammelten Mollusken. Beiträge zur Meeresfaun: der Insel Mauritius und der Seychellen. (Separate pagination).

\#Marty, T. 1789 Universal Conchology, vol. 3.

MoNTAGL, G. 1804 Description of several marine animals found on the south conat of Devonshire. Trans. Linn. Soc. London, Zool., vol. 7 .

Omin.R, N. 1931 Beiträge zur Malakozoologie der Kanarischen Inselen. Arkiv f. Zool., vol. 23 a, no. 14 .

O'Dosochur, C. H. 1929 Opisthobranchiate Mollusca collected by the South African Marine Biological Survey. Fish. Mar. Biol. Surv., rep. 7 , no. 1.

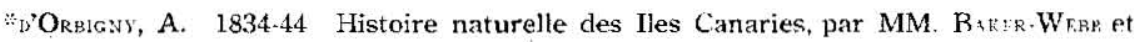
Sabia Berthloti, vol. 2.

Prase, W. H. 1860-61 Descriptions of new species of Mollusca from the Sandwich Islands. Proc. Zool. Soc. London.

1866 Remarks on Nudibranchiata inhabiting the Pacific Islands, with descrip. tions of two new genera. Amer. Journ. Conch., vol. 2.

1868 Descriptions of marine Gastropoda inhabiting Polynesia. Amer. Tourn. Conch., vol. 4 .

1871 Descriptions of Nudibranchiate Mollusca inhabiting Polynesia. Amer. Journ. Conch., vol. 6.

P1LSPRY, H. A. 1895-6 TRYoN's manual of Conchology; structure and systematic, vol. 16 (pp. 1-112, 1895; pp. 113-262, 1896).

"Qi:ui, J. R. C. and P. Galamb 1832 Voyage de découvertes de I'Astrolabe exécutr par ordre du Roi, péndant les années $1826,27,28$, 29, sous le commandement de M. J. Dumonr D'URvit.f, vol. 2.

"Rsnti, A. S. 1828 Histoire naturelle des Aplysiens, de l'ordre des Tectibranches.

Rısprac, J. 1928 Contribution a l'étude des Nudibranches Néo-Calédoniens. Faune Colon. Franç., vol. 2.

*Ruppell, E. and F. S. Leucrart 1828 Neue Wirbellose Thiere des Rothen Meeres. Atlas zu der Reise im nördlichen Afrika, div. 1, Zool., pt. 5.

SOFfKer, C. B. 1869 Conchologia iconica, or illustrations of the shells of molluscous animals. Monograph of the genus Aplysin.

Simfsos, W. 1855 Descriptions of some of the new marine Invertebrata from the Chinese and Japanese seds. Proc. Acad. Nat. Sci. Philadelphir.

T.3k, Iw. 1932 Miscellaneous notes on shells. 4. Venus, vol. 3, no. $f$.

-.... 1932 Notes on the sea-hare. Venus, vol. 3 , no. 5.

.... 1933 Miscellaneous notes on shells. 5-6. Venus, vol. 3, no, 6, vol. 4 , no. 1. 
Tumbs, J. 1930 Gastropoda und Bivalva. Die Fauna Sidwest-Australiens, vol. 5, no. 8 .

1931 Handbuch der systematischen Wejchtierkunde, pt. 2.

Torwe, S. 1914 Some animals interesting from ecolouical viewpoint. Dôbutsugaku Zasshi, vol. 26, no. 306 .

Vavstim, M. A. 1888 Recherches zoologiques et anatomiques sur les mollusques Opisthobranches du Golfe de Marseilie. 2. Nudibranches et Ascoglosses. Ann. Mus. Hist. Nat. Marseille, Zool., vol. 3.

1906, 1912 Recherches zoologiques et anatomiques sur les Opisthobranches de la Mer Rouge et du Golfe d'Aden. Ann. Fitc. Sci. Markeille, vol. 16, div. 2; vol. 20, suppl. 


\section{EXPLANATION OF THE PLATES}

\section{Plate 1.}

Fig. 1. Hexabranchus marginatus (QLì and Gamaku). $\quad \succ \frac{7}{3}$

Fig. 2. Asteronotus cespitosus (vas Hasini). $\times \frac{4}{\mathrm{a}}$

Fig. 3. Argus cruentus (Quir and Gamaky). $\quad \times 1$

Fig. 4. Dendrodoris (Dendrodoris) tuberculosa (QuUY and CAIM.R. $<1$

Plate 2.

Fig. 1. Macobranchus ocellatus vas Hasser.T. $\times 1.5$

Fig. 2. Elysiat yaeyamana nov. sp. $\times 1$

Fig. 3. Notarchus (Stylocheilus) stimpsoni Prsingr. 5

Fig. 4. Coryphella ornata Ristec. $\times 7$

Fig. 5. Dendrodoris (Dendrodoris) elongata nov. sp. $\quad 1$

Plate 3.

Jig. 1. Phylliaia (Phyllidiella) pustulosa Cuvıқ. $\therefore 1.2$

liig. 2. Dolabrifera tahitensis PIASt. $\times 1$

Fig. 3. Dendrodoris (Dendrodoris) nigrn (SMmpsun). $\times 1.5$

Fig. 4. Cyerce nigricans (P.AsF). $\times 2$

Fig. 5. Cieitodoris ohshimai nov. sp. $\times 2$

Fig. 6. Elysia viridis (Monranc), $\times 4$

Fig. 7. Nembrotha luteolineate nov. sp. $\times 2$

Fig. 8. Aglain cyanea (Martias). $\times 1.5$

Fig. 9. Cryptophthalmus smaragdinus (Rürptu, and I. ElckakT). $\quad \times 1.5$

Fig. 10. Argus csakii nov. sp. $\times 1.6$

Fig. 11. Discodoris yacyamensis nov. sp. $\div 1.6$ 


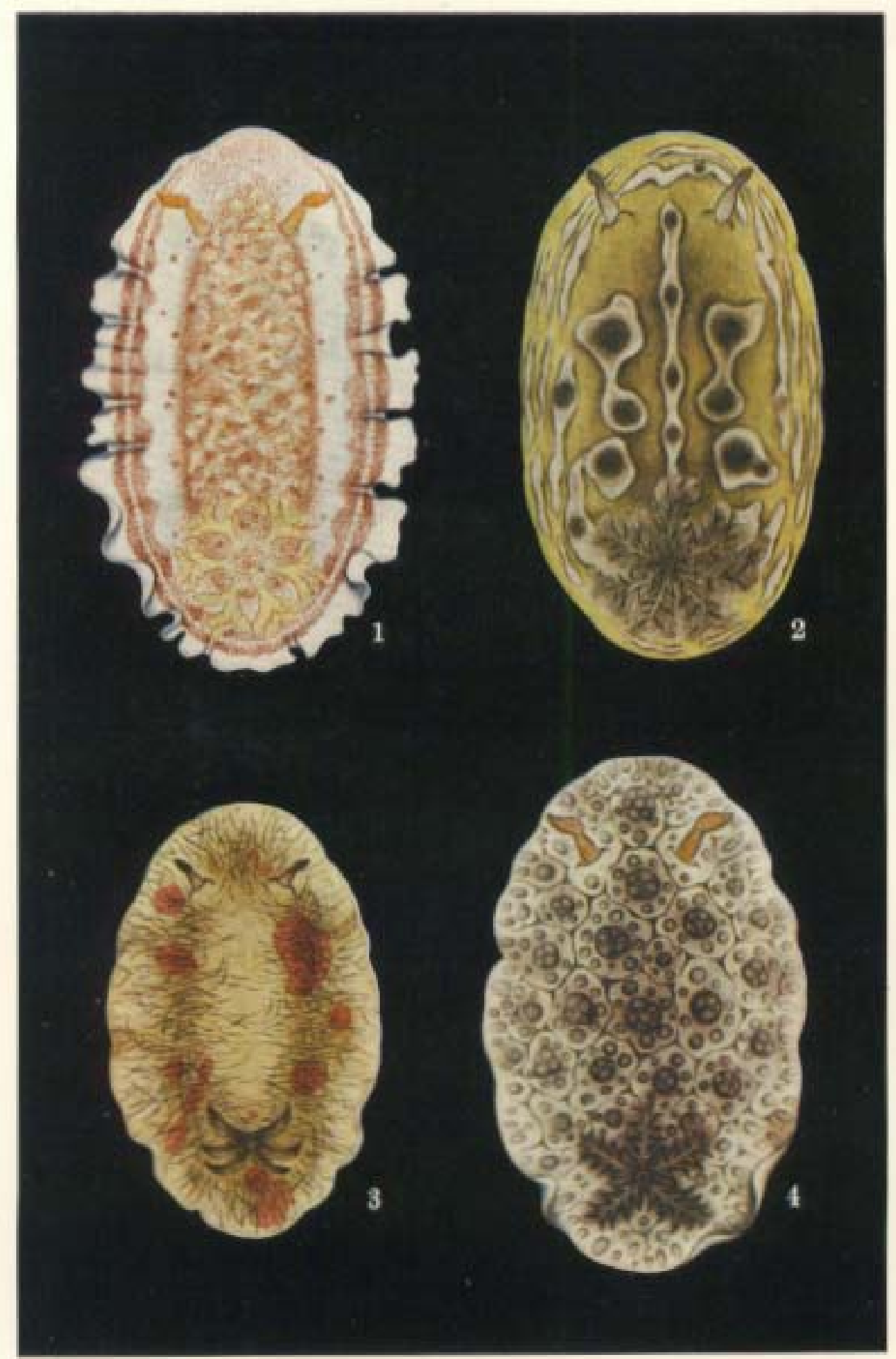




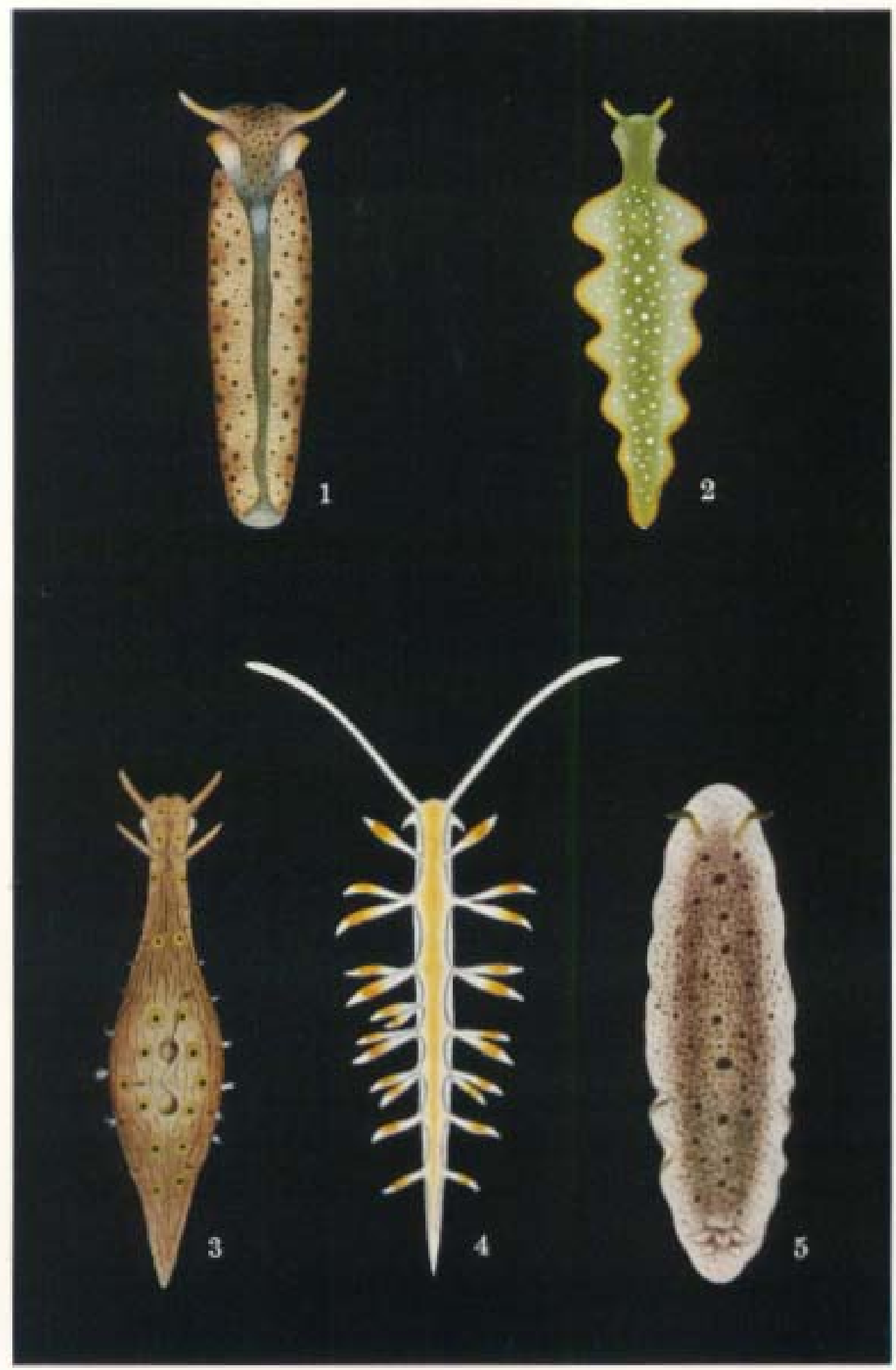


Jour. Dept. Agric. Kyushu Imp. Univ. Vol. 5

Plate 3
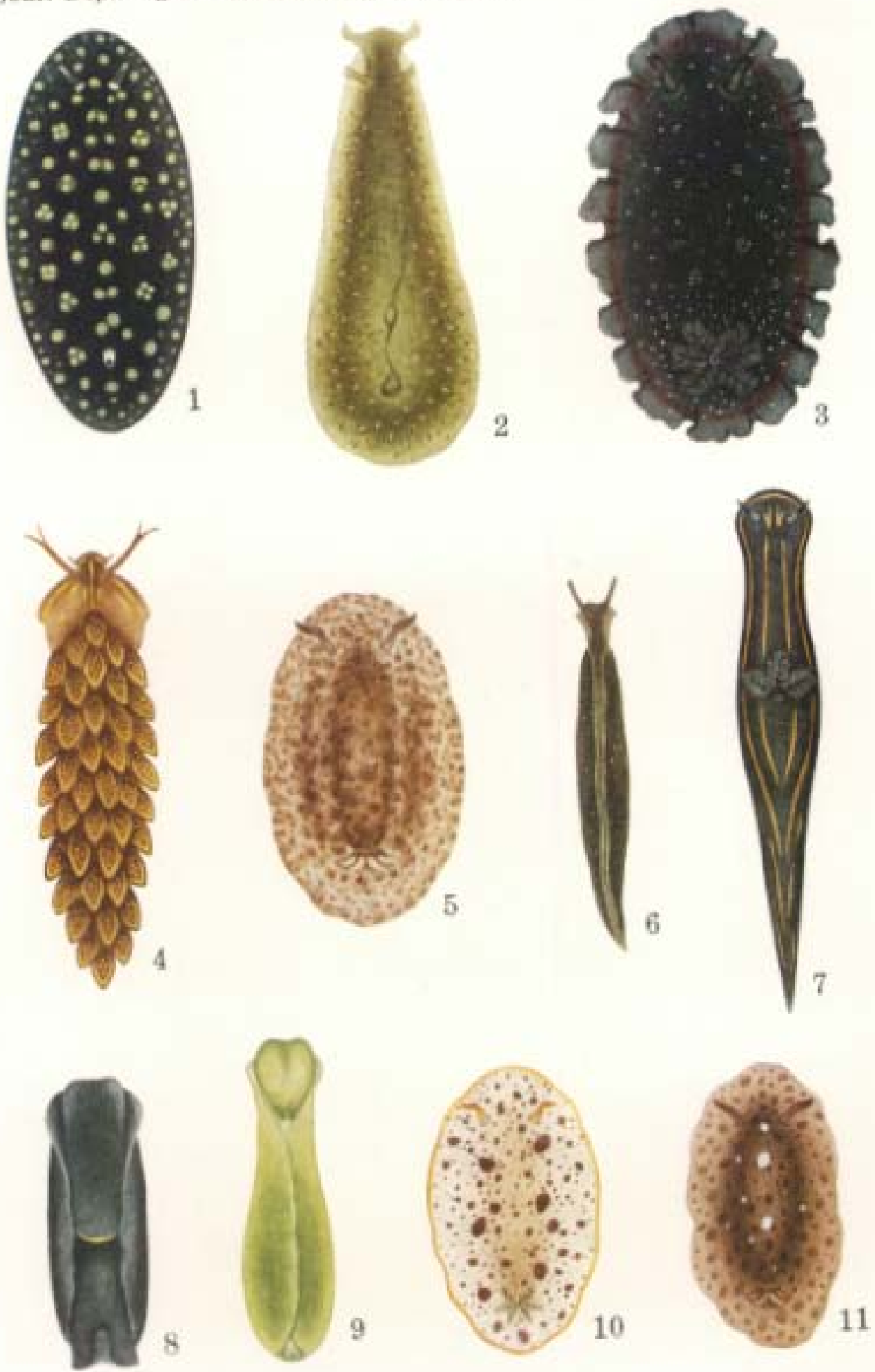